\title{
Sex selection of sperm in farm animals: status report and developmental prospects
}

\author{
D Rath, S Barcikowski ${ }^{1}$, S de Graaf ${ }^{2}$, W Garrels, R Grossfeld, S Klein, W Knabe ${ }^{3}$, C Knorr ${ }^{4}$, \\ W Kues, H Meyer ${ }^{5}$, J Michl ${ }^{6}$, G Moench-Tegeder, C Rehbock ${ }^{1}$, U Taylor and S Washausen ${ }^{3}$ \\ Institute of Farm Animal Genetics, Friedrich-Loeffler-Institut, Hoeltystrasse 10, 31535 Neustadt-Mariensee, Germany, \\ ${ }^{1}$ Institute of Technical Chemistry, Center for Nanolntegration Duisburg-Essen, CENIDE, University Duisburg-Essen, \\ Essen, Germany, ${ }^{2}$ Faculty of Veterinary Science, University of Sydney, Sydney, New South Wales, Australia, ${ }^{3}$ Institute \\ of Anatomy, University of Münster, Münster, Germany, ${ }^{4}$ Institute of Veterinary Medicine, University of Göttingen, \\ Göttingen, Germany, ${ }^{5}$ Laserzentrum Hannover e.V., Hannover, Germany and ${ }^{6}$ Institute of Anatomy, University of \\ Göttingen, Göttingen, Germany
}

Correspondence should be addressed to D Rath; Email: rath@tzv.fal.de

\begin{abstract}
Pre-selection of spermatozoa based on the relative DNA difference between X- and Y-chromosome bearing populations by flow cytometry is an established method that has been introduced into commercial cattle production. Although several important improvements have increased the sort efficiency, the fertilising ability of sexed spermatozoa based on offspring per insemination is still behind farmers' expectations. The main stress factors, especially on mitochondria, that reduce the lifespan of spermatozoa are described, and new technical as well as biological solutions to maintain the natural sperm integrity and to increase the sorting efficiency are discussed. Among these methods are the identification of Y-chromosome bearing spermatozoa by bi-functionalised gold nanoparticles and triplex hybridisation in vivo as well as new laser-controlled deflection system that replaces the deflection of spermatozoa in the electrostatic field. Additionally, as well as a new nonsurgical transfer system of spermatozoa into the oviduct of cows has been developed and allows a significant reduction of spermatozoa per transfer. Altogether, the improvements made in the recent years will allow a broader use of sex-sorted spermatozoa even in those species that require more cells than cows and sheep.

Reproduction (2013) 145 R15-R30
\end{abstract}

\section{Introduction}

In 2011, the world's population reached seven billion people and it is predicted that this figure will rise above ten billion by the turn of the century. In order to meet the global food demand associated with this population growth, it will be necessary to utilise modern biotechnologies to promote the sustainable production of animals and agricultural resources. The FAO has recognised that production of pre-sexed livestock by sperm or embryo sexing, when combined with other biotechnologies, genomics, proteomics or phenomics, for example sperm-mediated gene transfer (Kues et al. 2008b, De Cecco et al. 2010, Niemann et al. 2011), offers a promising breeding strategy to help meet the increased demand for food production.

Besides the long-term benefit, farmers can profit directly from the use of sexed spermatozoa by producing optimal proportions of males and females in their animal production systems. The use of sexed spermatozoa increases the rate of genetic progress, especially in combination with genomic selection of sires. It also has the potential to improve herd management and diminish the incidence of dystocia by avoiding male calves. Sex pre-selection also decouples the quantity of dairy replacement heifers from those required for milk production. In consequence, more meat and milk will appear at least for a certain while on the market and reduce prices for heifers and milk (De Vries et al. 2008). Other economic benefits are the production of replacement heifers and heifers for export to developing countries.

In mammals, sex is determined by gonosomes, where an $\mathrm{XX}$ chromosome combination determines a female, and an $X Y$ chromosome combination a male. As sex chromosomes differ significantly in length, a discrimination of X- and Y-chromosome bearing sperm populations is possible. Several methods to separate $X$ - and Y-chromosome bearing populations of ejaculates have been investigated, but thus far only quantitative, total DNA amount-based differentiation by flow cytometry has proven repeatedly successful and highly accurate. 
A possible alternative, interferometry should be mentioned; but the technique has yet to reach practical application (van Munster 2002). Several reports have described in detail the possibilities and limitations of flow cytometry, which requires the identification of individual spermatozoa. With current high-speed flow cytometry, enrichment of the desired sex $>90 \%$ can be obtained for most species. Although each spermatozoon has to be individually examined for DNA content, limiting the number of spermatozoa that can be sorted to $<20 \mathrm{million} / \mathrm{h}$, several million calves have been born after fertilisation with spermatozoa processed by this technique. In other species, the number of offspring born from artificial insemination (AI) or IVF with sexed spermatozoa is negligibly small.

Recent advances in sex-sorting strategies include innovations in fluid techniques, droplet handling, biological improvements and application of latest nanotechnology methods using gold bioconjugates, which together offer substantial future prospects for application in sperm sexing.

\section{Sex sorting of spermatozoa by flow cytometry}

After it was demonstrated that it is not possible to differentiate sex-specific markers by physical methods, Gledhill et al. (1982) published the first experiments on flow cytometry on spermatozoa, which were followed by further technical adaptations to these specific cells (Fulwyler 1977, Dean et al. 1978, Stovel et al. 1978, Pinkel et al. 1982, Garner et al. 1983, Johnson \& Pinkel 1986, Johnson et al. 1987a, 1987b, Johnson \& Clarke 1988). The first pre-sexed offspring using this technique were born in 1988 (Morrell et al. 1988). In principle, the sorting technique is based on quantitative flow cytometry, where spermatozoa, afore co-incubated and labelled with the DNA fluorescent dye Hoechst 33342 (Johnson \& Pinkel 1986), are hydrodynamically focused in a discontinuous droplet stream, which passes an u.v. laser beam. The orthogonal set-up of two detectors requires a precise orientation of the sperm head in front of the laser to resolve the small quantitative DNA difference between $\mathrm{X}$ - and Y-chromosome bearing spermatozoa. Before droplets disrupt from the discontinuous stream, the last hanging drop is charged according to the DNA content of the encased spermatozoon, which then passes an electrostatic field $(3000 \mathrm{~V})$, and droplets are deflected according to their charge. Sorted cells are pushed into a collection medium from where they are distributed to further preservation steps (Johnson \& Welch 1999b). This set-up allows identification and selection of individual spermatozoa with sort purity above $90 \%$ of the desired characteristics (Johnson \& Welch 1999b). Fine-tuning of the sorter hardware and acquisition software optimisation has been reported to allow a maximum sort rate of 8000 cells/s under ideal conditions (Sharpe \& Evans 2009).
This is equivalent to two conventional bovine $\mathrm{Al}$ doses produced per hour, or 14 doses if 2.1 million spermatozoa are used for insemination (Seidel et al. 1999). The numerical limits are even more obvious for sex-sorted porcine sperm and prevent commercial applications for this species because at least 50 million spermatozoa are required to achieve a pregnancy employing deep intra-uterine Al (Rath et al. 2003, Grossfeld et al. 2005). In horses, Lindsey et al. (2002) reported reasonable pregnancy results after hysteroscopic insemination with five million sperm.

During the sorting process, several stress factors have been identified that originate from four major sources: i) shear forces acting during the hydrodynamic focusing and passage through the injection nozzle; ii) the combination of the fluorescent dye bis-benzimide (Hoechst 33342) and cell exposure to certain wavelengths of the u.v. light spectrum; iii) repeated electrical doping corresponding to sperm DNA content and iv) the subsequent passage through the electrostatic deflection field. In addition to the sorting process itself, further impact on sperm quality is related to pre- and post-sort processes such as co-incubation with the fluorescent dye at slightly below body temperature and preservation at low temperature until insemination respectively.

Correct labelling of the condensed sperm chromatin is a prerequisite to identify DNA size differences of $<4 \%$. Hoechst 33342 (bis-benzimide) was found to be suitable for sperm DNA labelling as it passes the intact sperm membranes and preferentially binds to the AT-rich regions in the minor groove of the DNA helix (for review, see Rath \& Johnson (2008)). While Hoechst 33342 is apparently not genotoxic, it is known to be mutagenic to cells and may induce disturbances in embryo development. Moreover, the fate of Hoechst dye transported by the spermatozoon into the oocyte and thereby into the embryo and offspring is almost unknown (Garner 2009).

Since introduction, the sperm sexing technique has undergone several modifications in order to increase efficiency as well as its separation purity. Major improvements, including the use of a bevelled needle and an orientation nozzle tip with double elliptic torsions that promote the alignment of spermatozoa in front of the laser, were developed (Rens et al. 1998). These modifications resulted in a fourfold increase in the number of sorted spermatozoa produced per unit of time. Inserted into a high-speed flow cytometer, sort rates of 12-15 million spermatozoa per hour became a reality and were the prerequisite for commercial application (Johnson et al. 1999). While this 'HISON' orientating nozzle (Rens et al. 1998) had a double torsional elliptic shape, most commercial sorters today work with a further refined single torsion nozzle (Cytonozzle; $X Y$, Inc., Fort Collins, CO, USA) for better sperm orientation. Recently, we developed an updated version of the double torsional nozzle with an improved internal 
geometry in order to optimise the efficiency of sperm orientation. Moreover, the hydrodynamic focussing is amplified by the shape of the injection tube, which has a spattle-like shape with phased edges.

Since then, only minor technical modifications have been made to further improve the rate and purity of sorting. Attempts to minimise any adverse effects of the laser excitation on spermatozoa and to reduce the intensity from $150 \mathrm{~mW}$ to as low as $25 \mathrm{~mW}$ failed to improve fertility after Al in heifers (Schenk \& Seidel 2007) and after porcine embryo production (Guthrie et al. 2002). However, a positive effect on fertility was shown when the hydrodynamic pressure of the droplet stream was reduced from 50 to 40 psi (Schenk \& Seidel 2007, Schenk et al. 2009). Moreover, smaller technical adaptations of the general flow system such as reduced photomultiplier signal noise (Sharpe \& Evans 2009) and faster digital computing have also been implemented to improve the efficiency of sorting (Beckman-Coulter, MoFlo XDP, Krefeld, Germany). Software developments include a zoomed presentation, rotation of events and signal tracking to compensate for laser fluctuations (Beckman-Coulter Summit 4.0 and further).

\section{Recent advances in sex-sorting strategies}

\section{Labelling the sex of sperm with nanogold: gold nanoparticle design strategy}

A completely different approach focuses on a qualitative identification of sex-related differences in sperm. Numerous ineffective efforts were made in the past to bulk-separate spermatozoa by physical methods and qualitative surface markers but failed to be used on a wider scale (Cran \& Johnson 1996). A well-known difference of haploid spermatozoa is their difference in DNA sequences of $\mathrm{X}$ - and $\mathrm{Y}$-chromosomes. In vitro methods such as fluorescent in situ hybridisation are able to distinguish spermatozoa based on this information, but it requires the disintegration of the sperm head (Kawarasaki et al. 1998). Here we report on the status of our current stage of research employing functionalised gold nanoparticles (AuNPs) to identify Y-chromosomespecific sequences in morphologically and functionally intact sperm. Three major aspects have to be taken in account: i) penetration of functionalised AuNP through the sperm membranes, ii) non-invasive coupling of a specific DNA probe with the intact DNA double strand by triplex binding and iii) recognition of the sex-specific signal pattern to sort the sperm population.

\section{Delivering the nanogold label: cellular internalisation of AuNPs}

Interactions of NPs with cellular membranes are highly complex and depend on several intrinsic and extrinsic factors (Nel et al. 2009) that determine particle behaviour at the 'nano-bio-interface': The particle as such influences cellular uptake by its particular chemical composition as well as by steric aspects such as size, shape and ligands. The medium actuates the particle's electrochemical properties by providing $\mathrm{pH}$, ionic strength and temperature (Gao et al. 2005, Chithrani et al. 2006, Chithrani \& Chan 2007, Jiang et al. 2008, Arvizo et al. 2010, Zhang et al. 2010). Furthermore, NP uptake differs among cell types due to specific membrane fluidity, surface charge and functional molecules attached to the outer cell membrane. Such effects can be nicely exemplified when comparing, for instance, the influence of ligands on internalisation. While primary ligand-free AuNPs entered the cells by an unknown non-endosomal uptake mechanism (Salmaso et al. 2009, Taylor et al. 2010), AuNPs with ordered arrangements of hydrophilic and hydrophobic functional groups were internalised by membrane wrapping (Verma et al. 2008), and AuNP with citrate ligands underwent endocytosis (Shukla et al. 2000).

To increase the efficiency of NP uptake viral vectors (Everts et al. 2006), dendrimers (Shi et al. 2007) as well as peptides containing protein transduction domains (cell penetrating peptides (CPPs)) were used (Green \& Loewenstein 1988, Derossi et al. 1994, Lundberg \& Johansson 2002). Especially, the employment of CPPs showed promising results (Tkachenko et al. 2004, Nativo et al. 2008, Mandal et al. 2009). Nevertheless, successful internalisation depended strongly on the cargo itself as well as on peptide concentration (Stewart et al. 2008, Mandal et al. 2009). Some of them, such as penetratin, led to a tremendously enhanced uptake of AuNPs, but only into endosomes (Petersen et al. 2011). However, modification of AuNPs with Tat peptide, derived from the human immunodeficiency virus type- 1 , and also with a peptide named nucleus localisation signal caused the particles to directly enter into the cytosol and even into the nucleus (Tkachenko et al. 2004, de la Fuente \& Berry 2005, Berry et al. 2007).

\section{Anchoring the nanogold label: principle of signal recognition}

In addition to a membrane-penetration mediator, a nucleic acid probe is required to be conjugated to the AuNP for specific accumulation at the Y-chromosome. Therefore, such bivalent NPs will have to carry two different functional biomolecules at their surface, covalently bound via thiol linkers. To accomplish DNA hybridisation in non-denatured, chromatin triplex formation as described by Hoogsteen (1963) is necessary. As triplex hybridisation with DNA probes is rather weak, new DNA derivates, such as locked nucleic acids (LNA) and peptide nucleic acids, were developed to form more stable bindings (Johnson \& Fresco 1999a, Buchini \& Leumann 2003, Seidman \& Glazer 2003). In vitro AuNPconjugated LNA probes formed stable triplexes in 
solution (McKenzie et al. 2008). Even in situ triplex hybridisation without prior denaturation of the DNA could be achieved if suitable probes and protocols were used (Johnson \& Fresco 1999a, Schwarz-Finsterle et al. 2007). The detection principle is based on the fact that AuNPs that are aggregated or accumulated, for example due to binding of probes to highly repetitive DNA sequences, exhibit a bathochromic shift of the peak maximum as well as a significant increase of the extinction in the bathochromic regime of the spectrum (Jain et al. 2007). The detection limit for AuNP aggregate quantification was $35 \mathrm{fg}$, which is equivalent to a single aggregate with a diameter of $60 \mathrm{~nm}$ (Klein et al. 2010; Fig. 1).

\section{Sperm toxicity of AuNPS}

The question whether AuNP may cause toxic effects on mammalian cells is a matter of concern. In particular, detrimental effects on germ cells may become obvious in the following generation. After fusion of the gametes, a series of reprogramming events is activated, which includes DNA methylation, protamine exchange, histone marks, embryonic genome activation and degradation of maternal and paternal transcripts and proteins (Bermejo-Alvarez et al. 2008, Kues et al. 2008a). A well-orchestrated succession of these events is required to allow normal development, potentially making gametes and early embryos vulnerable to NPs, which may accumulate in the reproductive tract or which are intentionally added to spermatozoa in vitro (Bonde 2010, Ema et al. 2010, Schrand et al. 2010).

Information on the cytotoxicity of AuNPs is highly heterogeneous, which is mainly caused by the application to different cell lines and differently synthesised NPs; also experimental conditions are often not comparable. Only few studies investigated consequences of NP exposure on gamete and embryo development. AuNP are assumed to be relatively inert and less toxic than for example silver NPs (AgNPs). In vivo, an accumulation of AuNP was found in testes, as well as in liver and spleen of rats, which received i.v. injections of $20 \mathrm{~nm}$ AuNP. Thus, $20 \mathrm{~nm}$ AuNP seem to be able to cross the blood testis barrier (Balasubramanian et al. 2010). To address the size dependency of NPs, rats were injected with AuNP with diameters ranging from 10 to $250 \mathrm{~nm}$ (De Jong et al. 2008). In that study, the $10 \mathrm{~nm}$ AuNP showed the most widespread distribution in different organs, including the testis. However, only a relative small percentage of $0.2 \%$ of the total AuNP accumulated in the testis.

Few studies assessed the effects of NPs, and in particular AuNP, in IVF systems. As fertilisation comprises a number of successive steps, including capacitation, acrosome reaction, penetration of the zona pellucida, membrane fusion and cortical reaction, even subtle interferences may result in large consequences. A recent study in cattle supports the notion that concentrations of AuNPabove $50 \mu \mathrm{M}$ affect both motility of spermatozoa and fertilisation rates (Taylor et al. 2012).
1) Design
3) Selection

$\Delta d$

4) Detection

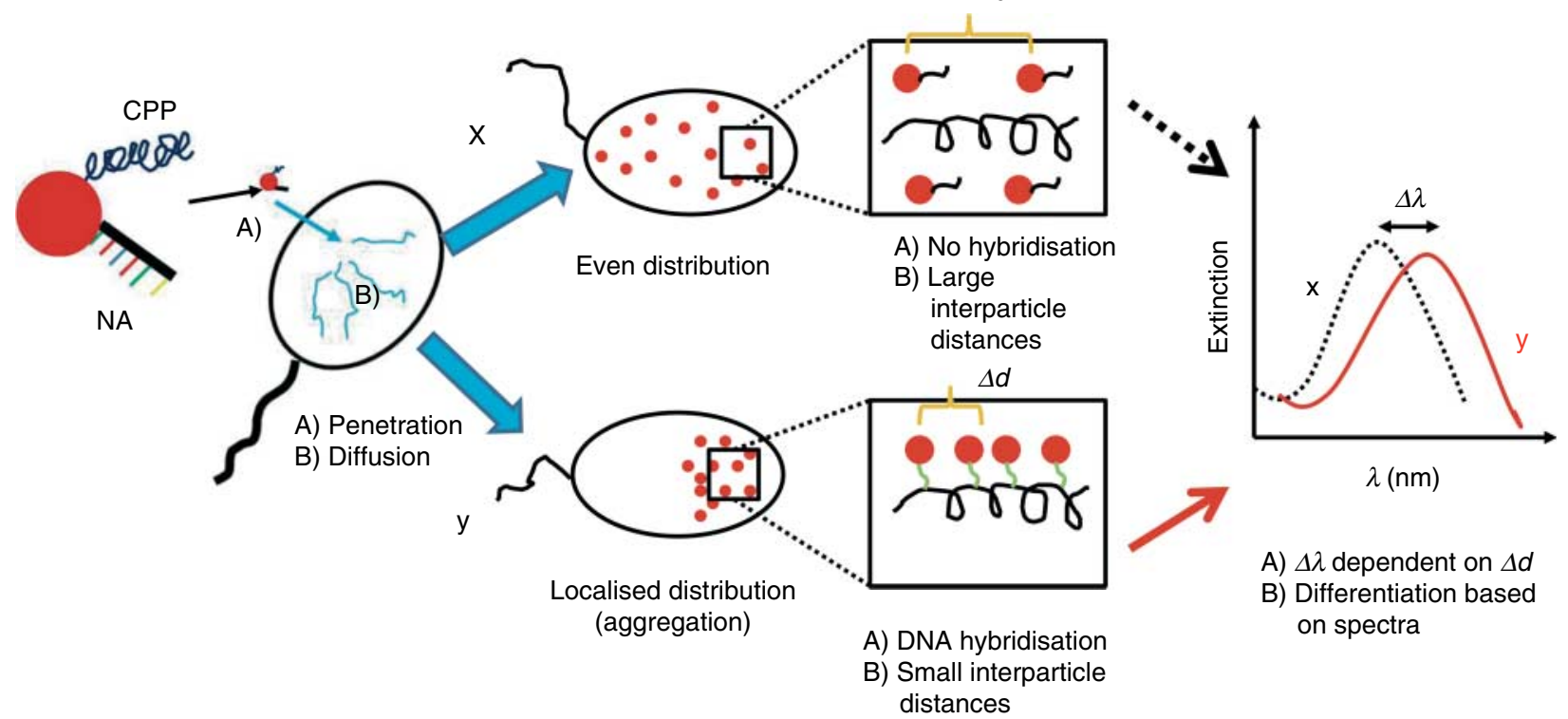

Figure 1 Nanoparticle-based sperm sorting. Optical detection principle based on the shift of the plasmon resonance peak upon regional accumulation of gold nanoparticles. (1) Design of a bivalent nano-bioconjugate with a cell penetrating peptide (CPP) and a hybridising nucleic acid (NA). (2) Cell penetration and distribution by diffusion. (3) Selective triplex formation at the $Y$ chromosome causes regioselective aggregation. (4) Aggregation causes a decrease of the interparticle distance $\Delta d$ and results in a bathochromic shift of the peak maximum. 
Another study demonstrated the occurrence of sublethal effects after incubation with $250 \mu \mathrm{M}$ AuNPs ranging in size from 3 to $50 \mathrm{~nm}$ in zebra fish embryos (Bar-Ilan et al. 2009). Besides these acute effects, whether chronic long-term effects may be initiated remains to be tested. So far only few studies assessed the toxicity of NP on spermatozoa of farm animals. The recent development of transgenic pigs with fluorophore-loaded spermatozoa (Garrels et al. 2011) may be instrumental for establishment of direct comparative tests.

\section{Droplet charging and deflection}

In addition to mechanical effects (De Ambrogi et al. 2006), repeated electric charging and electrostatic deflection $(3000 \mathrm{~V})$, which are necessary to sort sperm populations, are responsible for the reduced lifespan of sorted spermatozoa observed in most species (Spinaci et al. 2006, 2010, Rath \& Johnson 2008, Rath et al. $2009 b$ ). The electrostatic voltage is similar to that used for electroporation, causing a reversible transformation of membrane pores. Gagne et al. (1991) showed that electroporation of bovine spermatozoa reduced their in vitro fertility by about $30 \%$ after exposure to $500 \mathrm{~V}$. Similarly, electroporation induced the acrosome reaction in the sperm membranes of human spermatozoa (Tomkins \& Houghton 1988). These findings were confirmed indirectly by Maxwell \& Johnson (1997) who found capacitation-like patterns in the sperm membrane after sex sorting.

Exposure of cells to an electrostatic field, as it is used to separate the two sperm populations flow cytometrically, is known to induce formation of reactive oxygen species (ROS; Sauer et al. 2005), and it causes membrane damages to spermatozoa (Alvarez et al. 1987, Aitken et al. 1989, Leahy et al. 2010). Other than a physiological level of ROS, necessary for hyperactivation, capacitation and acrosome reaction in vitro (de Lamirande et al. 1997), excessive presence of ROS directly seems to affect sperm tail integrity (Klinc \& Rath 2007, Klinc et al. 2007). For stallion sperm, Baumber et al. (2000) and for human sperm, Shi et al. (2012) indicated that a decrease of the mitochondrial membrane potential caused by ROS is correlated with decreasing motility.

In order to detect ultrastructural changes caused to spermatozoa during the sorting process, bull sperm samples were collected at different steps during their passage through the flow cytometer. Our transmission electron microscopic analyses focused on mitochondria in the midpiece, which like glycolytic processes are thought to provide energy for motility in bull spermatozoa (Storey 2008, Piomboni et al. 2012). Sorted spermatozoa revealed a broad range of ultrastructural changes including among others gross disturbances of the helical arrangement of mitochondria and various degrees of mitochondrial swelling. However, the most remarkable ultrastructural finding was a significant switch from an orthodox to a condensed mitochondrial conformation, the latter being almost absent in native sperm (J Michl, University of Muenster, Germany; personal communication). Condensed mitochondria demonstrated a clear centre, composed of enlarged intracristal spaces, which was circumscribed by a rim of marginated condensed matrix (Fig. 2).

Ultrastructurally similar, if not identical changes from orthodox to condensed configurations of midpiece mitochondria have been noted under very different circumstances and conditions. Rahmy \& Ayoub (2002) reported that goat spermatozoa develop condensed mitochondria, referred to as 'mitochondria with distorted cristae' by the authors, after in vitro application of cobra venom. According to Rahmy \& Ayoub (2002), these ultrastructural alterations of the midpiece mitochondria may contribute to the observed reduction in sperm motility, viability and fertilising ability. Likewise, rapid cooling of ram spermatozoa results in the appearance of condensed mitochondria as well as in the irreversible reduction of sperm motility (Simpson et al. 1986). It has been clearly shown by Simpson et al. (1987) that even subtle influences can lead to a switch from orthodox to condensed mitochondrial forms. The authors used the ionophorous antibiotic A23187 to induce an increased uptake of calcium and oxygen in ram spermatozoa. As a result, mitochondria were significantly transformed from an orthodox to a condensed conformation at $\mathrm{pH}$ 8.0, but not at pH 7.0 (Simpson et al. 1987). Correspondingly, in mice deficient for the calcium extrusion pump membrane calcium ATPase 4 (PMCA4), intracellular calcium overload promotes an increase in the number of condensed sperm mitochondria, which failed to achieve hyperactivated motility (Okunade et al. 2004). Oscillatory ultrastructural modifications take place during rat spermatogenesis, transforming mitochondria from orthodox to condensed forms in spermatocytes and spermatids up to the early maturation phase (André 1962, De Martino et al. 1979). These condensed mitochondria, which require activin A from Sertoli cells for maintenance (Meinhardt et al. 2000), reverted to an 'orthodox-like' appearance during further maturation (De Martino et al. 1979).

It is assumed that transformation from an orthodox to a condensed conformation during sex sorting may influence energy production and motility of bull spermatozoa (J Michl 2012, personal communication). Our hypothesis is substantiated by recent evidence that ultrastructurally altered midpiece mitochondria among other mitochondria with dilated intermembrane spaces are associated with human asthenozoospermia (Pelliccione et al. 2011).

To avoid repeated charging and electrostatic stress during sex sorting, a new deflection method was developed (patent WO 2010/149739). The electrostatic deflection of the sperm droplet was replaced by laser 


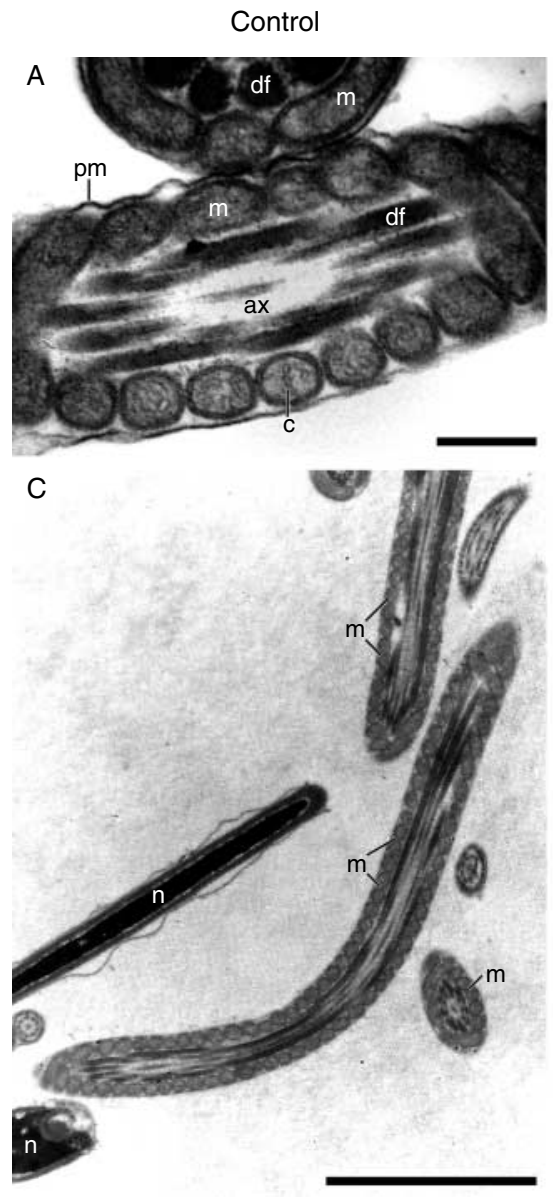

B
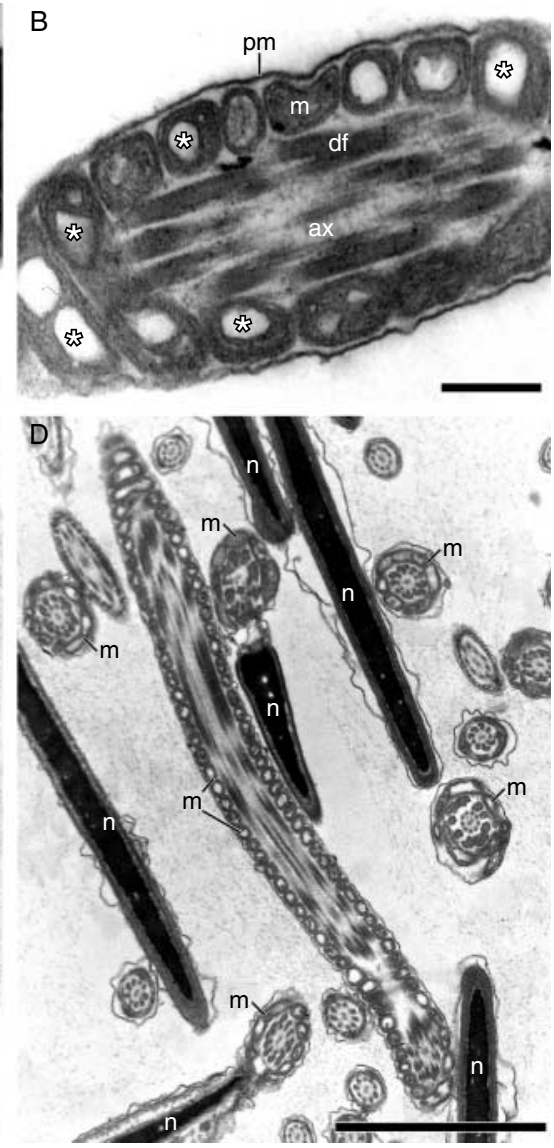

Sorted

Figure 2 Midpiece mitochondria of bull spermatozoa transform from an orthodox to a condensed configuration upon sex sorting. Transmission electron micrographs show unsorted controls (A and $\mathrm{C}$ ) and bulk sorted samples (B and D). (A) Orthodox mitochondria $(\mathrm{m})$ reveal lamellar cristae (c) and an electron translucent matrix. (B) Condensed mitochondria (some marked by asterisks) demonstrate enlarged intracristal spaces and a ringlike pheripheral condensation of electron dense matrix. (C and D) While orthodox mitochondria predominate in unsorted controls $(\mathrm{C})$, a high ratio of condensed mitochondria was found in sorted sperm samples (D). ax, axoneme; df, outer dense fibre; $n$, nucleus; pm, plasma membrane. Scale bars $=$ $200 \mu \mathrm{m}(\mathrm{A}$ and $\mathrm{B})$ or $2 \mu \mathrm{m}(\mathrm{C}$ and $\mathrm{D})$. irradiation of the droplet flow. The laser does not kill sperm with unwanted sex characteristics but deflects the droplet stream into the waste. Desired sperm pass the system without any deflection force. The emitted laser light from a DPSS Er+YAG laser (MIRPac, Laser Components, Olching, Germany) was used to generate recoil in the droplet by laser-based evaporation. About $70 \%$ of the laser light was absorbed according to the Lambert Beers law by the water droplet within the first micrometre, causing droplet evaporation. Consequently, a steam jet formation resulted in an acceleration of the droplet in the direction of the beam propagation. Owing to the high absorption coefficient of the liquid at this wavelength, damage of the spermatozoa by thermal interaction with the laser is not to be expected.

Laser induced evaporation on a droplet stream resulted in a droplet deflection of $2.8^{\circ}$ as depicted in Fig. 3.

Degree of motility and morphological integrity using phase contrast microscopy were compared 0 and $6 \mathrm{~h}$ after sorting of bovine spermatozoa in a sperm sorter assembled with either the usual electrostatic deflection system, or after implementation of the laser-based deflection system.

The results of six replicates indicate a significant difference $(P<0.05)$ for sperm motility between the two techniques (Fig. 4). Comparison of both parameters with non-sorted sperm of the same ejaculate showed no differences between laser deflected and unsorted sperm, whereas electrostatic spermatozoa lost $17 \%$ of motility within $6 \mathrm{~h}$ after sorting, confirming the advantages of the laser-based deflection system.

Recently, a promising patent was granted that replaces the orthogonal laser set-up with epifluorescence, a technique originally described by Van Dilla et al. (1977). When combined with a second laser system that kills sperm of the unwanted sex (Microbix, LumiSort, Missisauga, ON, Canada), such a machine may provide an alternative method for high speed sorting. Similarly, parallel sorting based on microchip technologies might avoid the complex orientation of spermatozoa and provide much higher rates of sorting.

\section{Recent biological improvements}

\section{Cattle}

The fertilising ability of sorted spermatozoa is highly related to their motility and membrane integrity. Sperm motility requires ATP synthesis. As spermatozoa are relatively poor generators of energy, their preservation 


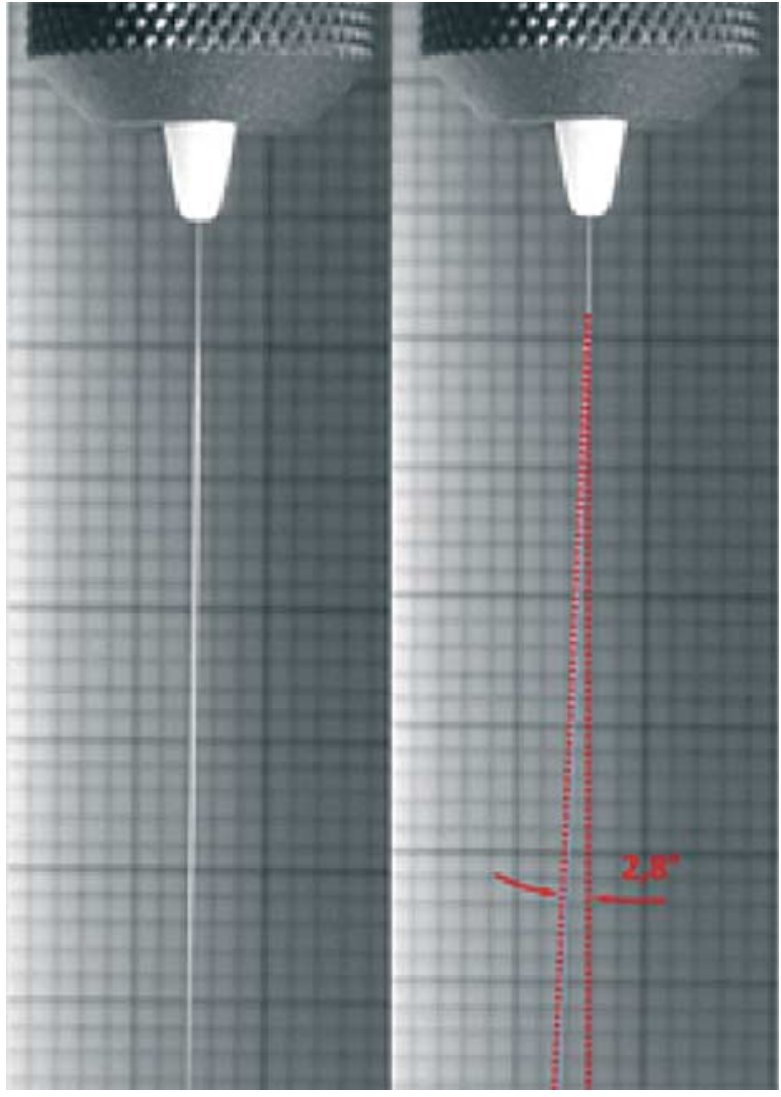

Figure 3 Deflection of the droplet stream by laser induced photo vapourisation. The left depiction shows an undeflected droplet stream from a sorter nozzle. The right image represents the deflection of the droplet stream by laser induced photo vaporisation with an $\mathrm{Er}^{+}$- $\mathrm{YAG}$ laser at an emission of $1 \mathrm{~W} \mathrm{cw}$ at $2.94 \mu \mathrm{m}$ wavelength.

aims to minimise their energy consumption. This is normally accomplished by storage at a low temperature. As it would be almost impossible to run a flow cytometer under such conditions, a reversible, chemical inhibition of motility could be an alternative. Sodium fluoride $(\mathrm{NaF})$ at low concentrations is able to reversibly stop the movement of spermatozoa (Zakrzewska \& Udala 2006) as it inhibits the activity of critical enzymes for ATP generation, such as alkaline phosphatases, ATPase, endolases and dehydrogenases (Chinoy et al. 1991, Zakrzewska et al. 2002, Liu et al. 2008, Sun et al. 2010). These enzymes play an important role in glycolysis, cell respiration, metabolism and protein syntheses and thereby are essential for sperm motility (Sun et al. 2010). The presence of $\mathrm{NaF}$ in the sample fluid improves the post-sort/post-thaw maintenance of sperm motility in cattle (Klinc 2005, Moench-Tegeder 2008, 2011, Rath et al. 2009a). This is important at the time of insemination. In a modified protocol to process spermatozoa before, during and after sorting (Sexcess; Rath et al. 2009b), the sample fluid is supplemented with NaF. Figure 5 shows the motility pattern of sex-sorted spermatozoa during a 6 - $\mathrm{h}$ thermo-tolerance test, indicating that no significant differences exist between sorted, using Sexcess and non-sorted frozen/thawed spermatozoa, whereas sorted spermatozoa treated with standard protocols lose their motility much faster within the first $3 \mathrm{~h}$ after thawing. Similar effects are also seen for membrane integrity (Moench-Tegeder 2008, Rath et al. $2009 b)$. In an initial field trial, Klinc (2005) showed that pregnancy rates equal to Al with unsorted frozen/thawed spermatozoa can be obtained from the Sexcess protocol. In a larger set-up with $2300 \mathrm{Al}$ on 19 farms in Saxony, Germany acceptable pregnancy rates were confirmed when semen was sorted accordingly. However, results in this trial indicated a bull-specific effect (Moench-Tegeder 2011). An interesting side effect seen in this field study was the increased number of stillbirth $(40 \%)$ in male calves originating from spermatozoa sorted for the $X$-chromosomal sperm population. Higher incidence of stillbirth in male calves were reported by DeJarnette et al. (2009) and Norman et al. (2010), whereas the stillbirth rate among female calves was not affected by sorting. Whether the effect is related to an accumulation of male spermatozoa with aneuploidy or whether epigenetic reasons may cause stillbirth requires further studies.

\section{Al strategies with sex-sorted sperm}

Conception rates to $\mathrm{Al}$ in cattle are related to sire, semen processing, sperm dosage and service number. For economic reasons, the number of spermatozoa in sorted samples is reduced to about two million sperm per dose, and this results in a pregnancy depression of $15-20 \%$ compared with unsorted spermatozoa (Dejarnette et al. 2011). Bull-related dilution effects may apply independently from sorting stress (Den Daas et al. 1998), but this remains unproven as Dejarnette et al. (2011) found that even the insemination of high numbers of sex-sorted spermatozoa (ten million) led to reduced pregnancy rates compared with unsorted spermatozoa inseminated at the same dose.

Even higher doses of spermatozoa are normally required for hormonally superovulated cows. The successful use of sexed spermatozoa in bovine multiovulation-embryo transfer (MOET) programmes critically depends on the $\mathrm{Al}$ dose; two million spermatozoa, as used for regular $\mathrm{Al}$, are insufficient (Schenk et al. 2006). The success after depositing higher doses of 10 to 20 million spermatozoa seems to be dependent on the sire or MOET conditions. Whereas Schenk et al. (2006) obtained lower fertilisation rates after Al with 20 million sex-sorted spermatozoa compared with controls, another study showed comparable fertility among groups when two inseminations were performed in 12-h intervals with five million sex-sorted spermatozoa (Hayakawa et al. 2009).

In human reproduction, gamete intra-fallopian transfer (GIFT) is an accepted tool to produce 
A Motility of sperms after electrostatic and laser deflection at 0 and $6 \mathrm{~h}$ incubation after sorting at $38^{\circ} \mathrm{C}$

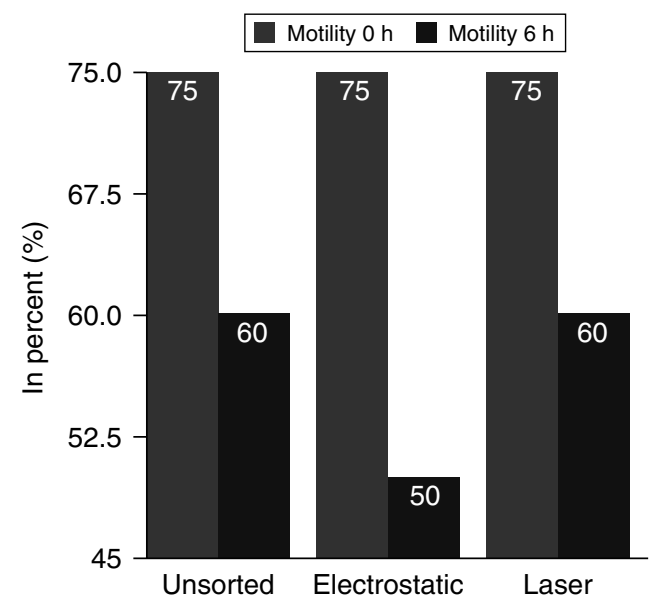

B

Morphologically intact sperms after electrostatic and laser deflection at 0 and $6 \mathrm{~h}$ incubation after sorting at $38^{\circ} \mathrm{C}$

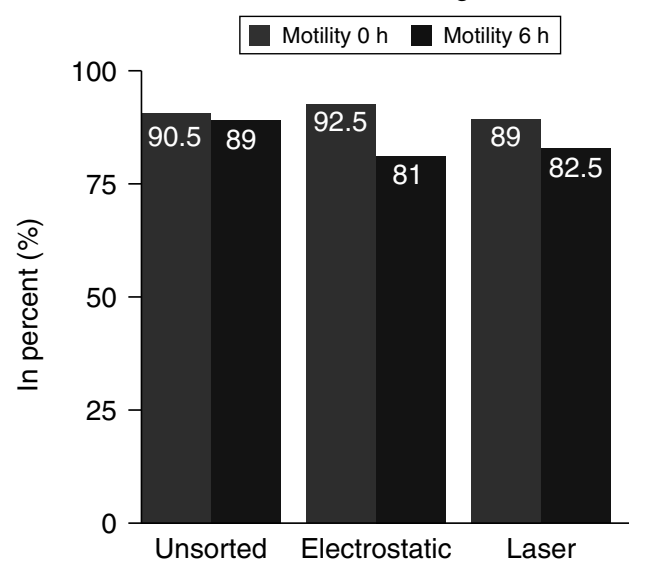

Figure 4 Deflection of the droplet stream by laser induced photo vapourisation. Comparison of motility and morphology with nonsorted sperm of the same ejaculate showed no differences between laser deflected and unsorted sperm, whereas electrostatic spermatozoa lost $17 \%$ of motility within $6 \mathrm{~h}$ after sorting, confirming the advantages of the laser-based deflection system.

pregnancies. For this method, instead of IVF, male and female gametes are transferred together into the oviduct. This has been tested successfully with sexed spermatozoa in pigs (Rath et al. 1994). Sperm intra-fallopian transfer replaces the intrauterine insemination with the deposition of spermatozoa directly into the oviduct. The new technique allows a significant reduction in the number of sorted cells required per insemination. Grossfeld et al. (2011) described a newly developed device for non-surgical transfer of sperm preparations in small volumes $\left(30 \mu \mathrm{l}, 10^{5}\right.$ sperm) directly into the bovine oviduct. In the first field trials, $41.2 \%$ of the cows became pregnant using this method. Such a technique has the potential to have a significant impact on the efficiency of utilisation of sex-sorted spermatozoa.

\section{IVF with sorted spermatozoa}

IVF is a routine technique that requires very low numbers of spermatozoa for embryo production. Therefore, it seems obvious to use sex-sorted spermatozoa in IVF. An early report on bovine IVF with sex-sorted spermatozoa, Cran et al. (1993) reported birth of the first calves where the sex was determined before fertilisation. Cleavage rates were similar to unsorted controls, but blastocyst development was diminished after IVF with sexed spermatozoa, presumably due to capacitation-like reorganisation of the sperm membranes (Merton et al. 1997, Lu et al. 1999). Later reports indicated negative effects of sorting on sperm integrity but neither cleavage rate nor blastocyst rates were affected if sperm were centrifuged with a Percoll gradient (Carvalho et al. 2010). Similar results were seen by Xu et al. (2006) after IVF with sex-sorted sperm and vitrification. Subsequent embryo transfer revealed no developmental differences of control groups to non-sexed IVF groups nor to in vivo produced embryos.

However, in comparison with their counterparts derived from unsorted spermatozoa, bovine IVF embryos derived from sex-sorted spermatozoa display a reduction in the relative abundance of developmentally important genes like glucose transporter 3 (Glut3) and glucose6-phosphate dehydrogenase (G6PD; Morton et al. $2007 a, 2007 b$ ), which may be deleterious to the developmental competence of embryos. In other studies cleavage rates after IVF with sex-sorted spermatozoa were $30 \%$ below those with unsorted spermatozoa from the same ejaculate. In this study, blastocyst formation on day 8 was $30-40 \%$ lower than for the controls (Bermejo-Alvarez et al. 2008), and the number of cell cycles were reduced (Beyhan et al. 1999). Additionally, significant sex related differences in polyA mRNA abundance were observed in day 7 blastocysts for the genes glutathione $S$-transferase M3 (GSTM3), DNA (cytosine-5)-methyltransferase 3A (DNMT3A) and progesterone receptor membrane component 1 (PGRMC1). The resulting embryos exhibited a delayed onset of the first cleavage (Bermejo-Alvarez et al. 2010).

IVF with sex-sorted spermatozoa also affects the ultrastructure of blastocysts. In particular, the mitochondria, rough endoplasmic reticulum and nuclear envelope showed deviations (Palma et al. 2008). Additionally, the authors showed a positive correlation of the percentage of progressively moving, sorted spermatozoa, and blastocyst development. IVF results are also affected by sperm concentration, which needs to be higher than for IVF with unsorted sperm, and by the hydrodynamic pressure used for sorting (BarceloFimbres et al. 2011). Although the sorting process has significant effects on sperm viability, and bull effects are obvious, compromised DNA does not affect reduced fertility as most non-viable spermatozoa, and those with aneuploidies are out-gated from sorting by parallel 
labelling with Hoechst 33342 and food dye \#40 (Warner Jenkinson, St Louis, MO, USA; Johnson \& Welch 1999b). Similarly, bisulphide sequencing of Nellore bull spermatozoa DNA indicated that the sorting process by flow cytometry does not affect the overall DNA methylation patterns of the insulin-like growth factor 2 (IGF2) and IGF2 receptor (IGF2R) genes in sperm, although individual variation in methylation patterns among bulls was observed (Carvalho et al. 2012).
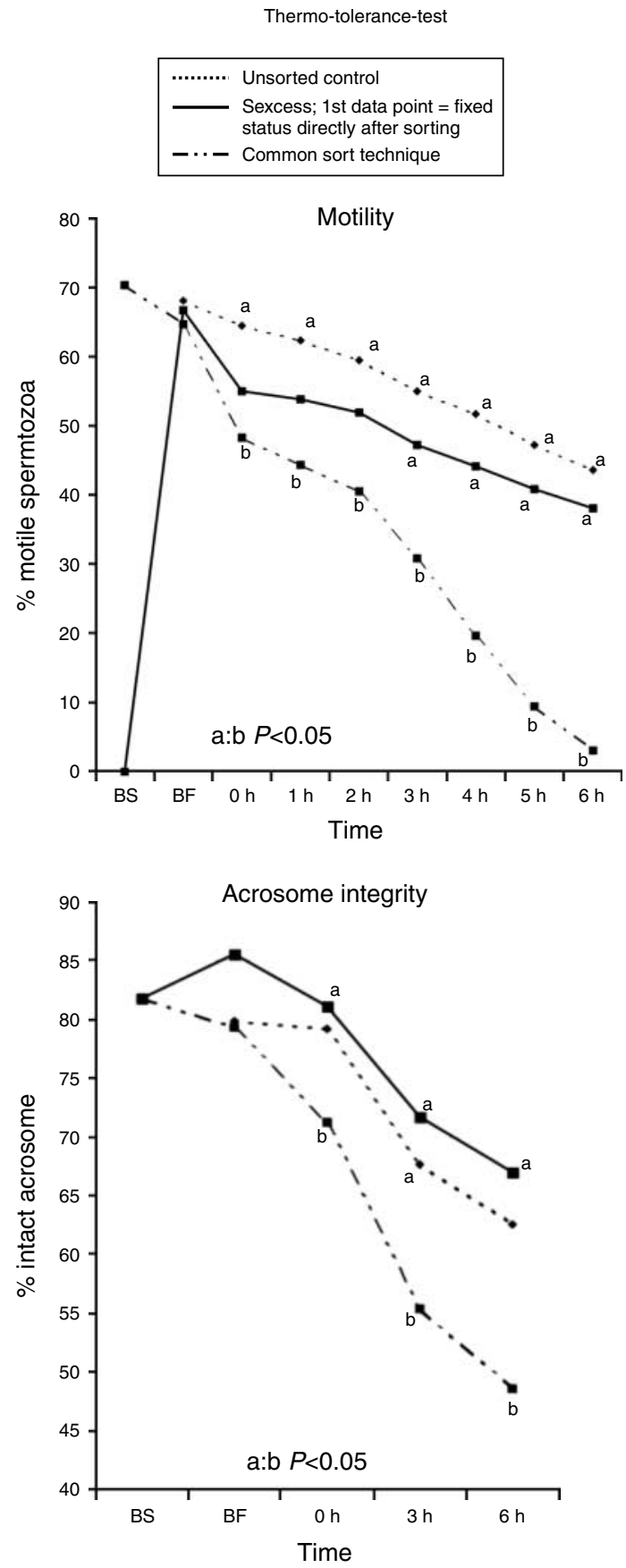

Figure 5 Thermo-tolerance test for motility and acrosome integrity of sex sorted, frozen/thawed spermatozoa using different sperm treatments.

\section{Sex-sorted porcine spermatozoa}

For the swine industry, sex-sorted spermatozoa would have major applications, for example to avoid castration. However, because of the high number of sperm required for $\mathrm{Al}$, the flow cytometric method is far too slow and inefficient to satisfy biological and commercial demands. Theoretically, the number of spermatozoa necessary for $\mathrm{Al}$ can be reduced from three billion to ten million if semen is deposited directly in front of the utero-tubal junction (Krueger \& Rath 2000), whereby uterine mechanisms of sperm selection are circumvented (Schuberth et al. 2008, Taylor et al. 2008, 2009a, 2009b, 2009c). Accordingly, a suitable insemination instrument has been developed for deep intrauterine Al (Martinez et al. 2001, Rath et al. 2003, Vazquez et al. 2003, Grossfeld et al. 2005), and pregnancies were obtained when only 50-100 million sorted sperm were inseminated into the tip of the uterine horn. Further reduction could be obtained after laparoscopic insemination into the oviduct (Vazquez et al. 2005).

For limited applications, embryo transfer may be an alternative to Al. The first IVF pig embryos derived via sexed sperm were produced in 1993 (Rath et al. 1993) with the first pregnancies attained 3 years later (Rath et al. 1997, 1999, Abeydeera et al. 1998). Despite this success, the system never reached a commercially applicable standard, as the litter size was low compared with the unsorted controls.

In vitro sexed spermatozoa have a tendency for polyspermic oocyte penetration. An alternative is to utilise ICSI, a highly efficient method using only a single sperm cell that is mechanically introduced into the ooplasm (Probst \& Rath 2003). The limitations of this technique are the expensive equipment required, and the need for surgical transfer of the resulting early stage embryos into the oviduct. With current laboratory protocols, later stage embryos are difficult to obtain in vitro after ICSI.

For practical reasons, GIFT into the oviduct may have advantages over IVF and has been demonstrated in pigs (Rath et al. 1994) in combination with surgical intervention. However, to use GIFT as a broader application, much emphasis has to be focussed on the development of non-surgical access to the oviduct. First developmental steps have been demonstrated (Vazquez et al. 2008).

\section{Sex-sorted ovine spermatozoa}

The use of sexed spermatozoa has genetic, management and financial benefits for sheep production enterprises, whether they are dairy, wool and/or meat. The use of IVF and ICSI is generally not commercially relevant in these industries, so sex-sorting research in sheep 
has focused on delivery of sexed, frozen semen by laparoscopic intrauterine AI.

Early experiments showed that sex-sorted, frozenthawed ram spermatozoa were functionally compromised to a similar extent to that of cattle, with reduced fertility following $\mathrm{Al}$ when compared with non-sorted, frozen controls (Hollinshead et al. 2002). In vitro assessment of sex-sorted ram spermatozoa showed a population of cells with reduced post-thaw motility and longevity as well as a tendency towards premature capacitation (Hollinshead et al. 2003). Combining these findings suggested that sex-sorted ram spermatozoa had a reduced fertilising lifespan, which would explain the aforementioned decrease in fertility. In subsequent field experiments, these fertility problems were shown to be partly ameliorated by insemination of larger numbers of sexed cells (Hollinshead et al. 2003), but this was an unpalatable solution considering the commercial imperative to minimise the number of sexed spermatozoa per Al dose. Fortunately, with increased stability of the flow cytometer and modifications to the cryopreservation process of the sexed cells, the function and fertility of sexed ram spermatozoa dramatically improved.

It has since been established that sex-sorted ram spermatozoa break the dogma that sex sorting by flow cytometry has a negative impact on the function and fertility of spermatozoa from all species (de Graaf et al. 2009). Ram spermatozoa, which have been sex sorted, exhibit higher motility, viability, acrosome integrity and mitochondrial activity than non-sorted controls (de Graaf et al. 2006). These in vitro results are supported by in vivo studies demonstrating that sex-sorted ram spermatozoa result in similar or superior fertilisation/ lambing percentages to non-sorted controls, when artificially inseminated into non-superovulated ewes in very low numbers (de Graaf et al. 2007c, Beilby et al. 2009; one million motile spermatozoa/ewe) or when sorted from previously frozen samples and re-frozen (de Graaf et al. 2007b); known as 'reverse sorting' or into superovulated animals used in MOET programs (de Graaf et al. 2007a). It appears that the sex-sorting process selects a highly functional sub-population of spermatozoa from the ejaculate, which results in sexed ram spermatozoa demonstrating a superior fertilising lifespan inside of the female reproductive tract compared with unsorted spermatozoa from the same ejaculate (Beilby et al. 2009). This beneficial effect of sorting is also observed when sex-sorted ram spermatozoa are used for IVF (Beilby et al. 2010).

While there is no apparent (negative) effect on fertility, ram spermatozoa are not left unchanged by the process of sex sorting by flow cytometry. Sex-sorted ram spermatozoa exhibit reduced velocity characteristics and cervical mucus penetration (de Graaf et al. 2006) as well as increased susceptibility to oxidative damage by hydrogen peroxide compared with their unsorted counterparts (Leahy et al. 2010). In addition, ovine embryos fertilised in vivo with sex-sorted spermatozoa display down-regulation of G6PD and SLC2A3 gene transcripts, but with no apparent effect on embryo development (Beilby et al. 2011). The importance of these changes are easy to overlook given the lack of an effect on fertility, but they perhaps shed some light on potential sub lethal damage that occurs during the sorting process that may be of more significance in other species with a reduced tolerance to the stressors of flow cytometry or less supportive sorting protocols.

Whatever the case, the recent fertility successes with sheep are an encouragement to investigators working to improve the fertility of sexed spermatozoa in other species and make sex pre-selection technology a commercially viable and effective reproductive management option for the sheep industry.

\section{Reverse sorting}

The previous section touched on a procedure known as 'reverse sorting', which has become popular in recent times as it allows previously frozen spermatozoa to be separated for sex. This technique is useful for males that are located a great distance from a sex-sorting site or which are deceased and thus unable to provide fresh ejaculates for sex sorting. The modern 'reverse sorting' technique overcomes the resolution and staining problems observed by early investigators (Stap et al. 1998) by washing frozen spermatozoa through a density gradient and thereby removing the dead cells, glycerol and egg yolk, which may interfere with the staining process or negatively impact on the physiology of the remaining viable cells (O'Brien et al. 2003, Underwood et al. 2009a).

The first pre-sexed offspring produced from frozenthawed, sex-sorted re-frozen-thawed spermatozoa were achieved in sheep following IVF and embryo transfer (ET) (Hollinshead et al. 2004) and some years later using Al (de Graaf et al. 2007b). Notably, in the latter study, frozen-thawed, sex-sorted, re-frozen-thawed ram spermatozoa had similar fertility to sex-sorted and even nonsorted controls. These in vivo findings were supported by in vitro data, which showed that frozen-sorted-refrozen ram spermatozoa, while slightly inferior to spermatozoa sex-sorted from fresh samples, still had higher motility, acrosome integrity, viability and mitochondrial activity than frozen-thawed controls (de Graaf et al. 2006). As with normal sex-sorted samples, frozen-sortedrefrozen spermatozoa displayed reduced velocity characteristics and ability to penetrate artificial cervical mucus, but the in vivo findings of de Graaf et al. (2007b) suggest that these functional alterations have a minimal bearing on fertility.

Unfortunately, similar success with reverse sorting has not been shared by cattle. Reverse sorted re-frozen bull spermatozoa display poorer motility and viability in vitro, particularly after incubation, when compared 
with frozen-thawed controls (Underwood et al. 2009b). While pre-sexed calves have been born following AI of frozen-sorted-refrozen bull spermatozoa, fertility is very low (Underwood et al. 2010b) and characterised by pregnancy loss (Underwood et al. 2010a). Greater success has been achieved with the use of frozen-sorted-refrozen bull spermatozoa in IVP systems where cleavage and blastocyst production have been comparable to that obtained with sex-sorted frozen spermatozoa and non-sorted frozen controls (Underwood et al. 2010c).

The reason for the varied success of the 'reverse sorting' technique between sheep and cattle is no doubt related to the species variation in fertility of sex-sorted spermatozoa mentioned earlier in this review. The reason for this difference between the species is the source of some debate (de Graaf et al. 2009) and has yet to be determined. A greater understanding of this issue would likely bring improvements to the fertility of sex-sorted re-frozen bull spermatozoa, and perhaps further development of this technique in other species. To date, only the bottlenose dolphin (O'Brien et al. 2009) has joined cattle and sheep in the production of pre-sexed offspring from frozen-sorted-refrozen spermatozoa, but preliminary development of sorting protocols continues in a number of other wildlife and domestic species.

\section{Sex-sorted equine spermatozoa}

The limitations of equine Al with sex-sorted spermatozoa are similar to those in pigs. Normal $\mathrm{Al}$ in mares requires 0.5 to 1 billion spermatozoa. Buchanan et al. (2000) reported the birth of the first foal after non-surgical Al with sex-sorted spermatozoa. Two methods helped to reduce the insemination dose. A non-surgical method was described by Buchanan et al. (2000), who introduced a flexible Al catheter deep into the uterine horn. More effective was the hysteroscopic insemination, where spermatozoa are deposited directly onto the uterine papilla, the entrance of the utero-tubal junction (Rigby et al. 2001). The success seems to be dose dependent as Morris et al. (2000) found an increasing pregnancy rate from $29 \%$ (0.5 million spermatozoa) to $75 \%$ (five million spermatozoa). Higher dosages did not result in higher pregnancy rates. Sortability varies among stallions and ejaculates. Post-thaw survival of spermatozoa depends on the extenders used for sorting and freezing (Clulow et al. 2008, Gibb et al. 2011, Balao da Silva et al. 2012). A good method to rank stallions and predict their usability for sorting and freezing is the microscopic determination of the percentage of dead sperm (Clulow et al. 2009).

A modified freezing protocol significantly improved the post-thaw quality of sex-sorted spermatozoa (Heer 2007). The author sorted equine spermatozoa in the presence of different antioxidants and pre-selected spermatozoa after collection by density gradient centrifugation. In consequence, a significantly higher percentage of morphologically normal spermatozoa and viable, non-acrosome reacted spermatozoa as well as a significantly lower percentage of dead spermatozoa were obtained after sorting and freezing/thawing compared with samples that were prepared in the conventional way.

\section{Conclusions and outlook}

Despite more than 30 years of development, commercial operations that utilise sperm sorting by flow cytometry to pre-select the sex of offspring remain largely restricted to applications in cattle. In other farm animals, only marginal numbers of offspring have been born, and commercial availability of the sorting technology remains limited. Even though the speed of sorting has greatly increased during this time period, each individual spermatozoon still needs to be assessed and sorted accordingly. In consequence, the sperm dosage for Al in all species has to be reduced, which has negative impacts on fertility and has contributed greatly to the limited introduction of sexed spermatozoa into the breeding market.

Several improvements have recently made sperm sorting more efficient and less harmful for spermatozoa. The future use of inert AuNPs and a harmless deflection method are two specific modifications, which show great promise to improve the longevity and fertilising capacity of sorted spermatozoa. Besides the technical improvements, several biological adaptations have been developed and have increased the sort efficiency and post-sort sperm quality. In combination with other techniques such as IVF, ICSI or intra-tubal sperm transfer, it is very likely that sexed spermatozoa will be used in those species where higher numbers of spermatozoa are usually required.

\section{Declaration of interest}

The authors declare that there is no conflict of interest that could be perceived as prejudicing the impartiality of the research reported.

\section{Funding}

This work was supported by 'Deutsche Forschungsgemeinschaft', Priority Programme 1313 'Nano-Bio-Response', the Cluster of Excellence 'REBIRTH', NBank Lower Saxony, Masterrind $\mathrm{GmbH}$ Verden and the Regional Authorities of Saxony for Environment, Agriculture and Geology.

\section{Acknowledgements}

We kindly acknowledge the skilled assistance of C Maxwell, A Barchanski, S Petersen, P Klinc, S Freese, A Frenzel, B Sieg, C Struckmann and I Weiss, who participated in the experiments 
and/or assisted in the preparation of this review. S Barcikowski, S de Graaf, W Garrels, R Grossfeld, S Klein, W Knabe, C Knorr, W Kues, H Meyer, J Michl, G Moench-Tegeder, D Rath, C Rehbock, U Taylor and S Washausen have contributed equally to this work.

\section{References}

Abeydeera LR, Johnson LA, Welch GR, Wang WH, Boquest AC, Cantley TC, Rieke A \& Day BN 1998 Birth of piglets preselected for gender following in vitro fertilization of in vitro matured pig oocytes by $\mathrm{X}$ and $\mathrm{Y}$ chromosome bearing spermatozoa sorted by high speed flow cytometry. Theriogenology $\mathbf{5 0}$ 981-988. (doi:10.1016/S0093-691X (98)00201-5)

Aitken RJ, Clarkson JS \& Fishel S 1989 Generation of reactive oxygen species, lipid peroxidation, and human sperm function. Biology of Reproduction 41 183-197. (doi:10.1095/biolreprod41.1.183)

Alvarez JG, Touchstone JC, Blasco L \& Storey BT 1987 Spontaneous lipid peroxidation and production of hydrogen peroxide and superoxide in human spermatozoa. Superoxide dismutase as major enzyme protectant against oxygen toxicity. Journal of Andrology 8 338-348.

André J 1962 Contribution à la connaissance du chondriome. Journal of Ultrastructure Research 6 (Supplement 1) 1-185. (doi:10.1016/S08891605(62)80002-0)

Arvizo RR, Miranda OR, Thompson MA, Pabelick CM, Bhattacharya R, Robertson JD, Rotello VM, Prakash YS \& Mukherjee P 2010 Effect of nanoparticle surface charge at the plasma membrane and beyond. Nano Letters 10 2543-2548. (doi:10.1021/nl101140t)

Balao da Silva C, Macias-Garcia B, Morillo Rodriguez A, Gallardo Bolanos JM, Tapia JA, Aparicio IM, Morrell JM, RodriguezMartinez H, Ortega-Ferrusola C \& Pena FJ 2012 Effect of Hoechst 33342 on stallion spermatozoa incubated in KMT or tyrodes modified INRA96. Animal Reproduction Science 131 165-171. (doi:10.1016/j. anireprosci.2012.01.003)

Balasubramanian SK, Jittiwat J, Manikandan J, Choon-Nam O, Liya EY \& Wei-Yi O 2010 Biodistribution of gold nanoparticles and gene expression changes in the liver and spleen after intravenous administration in rats. Biomaterials 31 2034-2042. (doi:10.1016/j.biomaterials. 2009.11.079)

Barcelo-Fimbres M, Campos-Chillon LF \& Seidel GE Jr 2011 In vitro fertilization using non-sexed and sexed bovine sperm: sperm concentration, sorter pressure, and bull effects. Reproduction in Domestic Animals 46 495-502. (doi:10.1111/j.1439-0531.2010.01696.x)

Bar-llan O, Albrecht RM, Fako VE \& Furgeson DY 2009 Toxicity assessments of multi-sized gold and silver nanoparticles in zebrafish embryos. Small 16 1897-1910. (doi:10.1002/smll.200801716)

Beilby KH, Grupen CG, Thomson PC, Maxwell WMC \& Evans G 2009 The effect of insemination time and sperm dose on pregnancy rate using sex-sorted ram sperm. Theriogenology 71 829-835. (doi:10.1016/ j.theriogenology.2008.10.005)

Beilby KH, de Graaf SP \& Grupen CG 2010 The effect of sperm and cryoprotectant concentration on the freezing success of sex sorted ram sperm for in vitro fertilization. Theriogenology 74 786-794. (doi:10.1016/j.theriogenology.2010.04.003)

Beilby KH, de Graaf SP, Evans G, Maxwell WMC, Wilkening S, Wrenzycki C \& Grupen CG 2011 Quantitative mRNA expression in ovine blastocysts produced from X- and Y-chromosome bearing sperm, both in vitro and in vivo. Theriogenology 76 471-481. (doi:10.1016/j. theriogenology.2011.02.024)

Bermejo-Alvarez P, Rizos D, Rath D, Lonergan P \& Gutierrez-Adan A 2008 Can bovine in vitro-matured oocytes selectively process $\mathrm{X}$ - or Y-sorted sperm differentially? Biology of Reproduction 79 594-597. (doi:10.1095/ biolreprod.108.070169)

Bermejo-Alvarez P, Lonergan P, Rath D, Gutierrez-Adan A \& Rizos D 2010 Developmental kinetics and gene expression in male and female bovine embryos produced in vitro with sex-sorted spermatozoa. Reproduction, Fertility, and Development 22 426-436. (doi:10.1071/RD09142)
Berry CC, de la Fuente JM, Mullin M, Chu SWL \& Curtis ASG 2007 Nuclear localization of HIV-1 tat functionalized gold nanoparticles. IEEE Transactions on Nanobioscience 6 262-269. (doi:10.1109/TNB.2007. 908973)

Beyhan Z, Johnson LA \& First NL 1999 Sexual dimorphism in IVM-IVF bovine embryos produced from $X$ and $Y$ chromosome-bearing spermatozoa sorted by high speed flow cytometry. Theriogenology 52 35-48. (doi:10.1016/S0093-691X(99)00108-9)

Bonde JP 2010 Male reproductive organs are at risk from environmental hazards. Asian Journal of Andrology 12 152-156. (doi:10.1038/aja. 2009.83)

Buchanan BR, Seidel GE Jr, McCue PM, Schenk JL, Herickhoff LA \& Squires EL 2000 Insemination of mares with low numbers of either unsexed or sexed spermatozoa. Theriogenology 53 1333-1344. (doi:10.1016/S0093-691X(00)00276-4)

Buchini S \& Leumann CJ 2003 New nucleoside analogues for the recognition of pyrimidine-purine inversion sites. Nucleosides, Nucleotides \& Nucleic Acids 22 1199-1201. (doi:10.1081/NCN-120022835)

Carvalho JO, Sartori R, Machado GM, Mourão GB \& Dode MA 2010 Quality assessment of bovine cryopreserved sperm after sexing by flow cytometry and their use in in vitro embryo production. Theriogenology 74 1521-1530. (doi:10.1016/j.theriogenology.2010.06.030)

Carvalho JO, Michalczechen-Lacerda VA, Sartori R, Rodrigues FC, Bravim O, Franco MM \& Dode MA 2012 The methylation patterns of the IGF2 and IGF2R genes in bovine spermatozoa are not affected by flow-cytometric sex sorting. Molecular Reproduction and Development 79 77-84. (doi:10.1002/mrd.21410)

Chinoy NJ, Sequeira E \& Narayana MV 1991 Effects of vitamin C and calcium on the reversibility of fluoride-induced alterations in spermatozoa of rabbits. Fluoride 24 29-39.

Chithrani BD \& Chan WCW 2007 Elucidating the mechanism of cellular uptake and removal of protein-coated gold nanoparticles of different sizes and shapes. Nano Letters 7 1542-1550. (doi:10.1021/ nl070363y)

Chithrani BD, Ghazani AA \& Chan WCW 2006 Determining the size and shape dependence of gold nanoparticle uptake into mammalian cells. Nano Letters 6 662-668. (doi:10.1021/nl0523960)

Clulow JR, Mansfield LJ, Morris LH, Evans G \& Maxwell WM 2008 A comparison between freezing methods for the cryopreservation of stallion spermatozoa. Animal Reproduction Science 108 298-308. (doi:10.1016/j.anireprosci.2007.08.014)

Clulow JR, Evans G, Morris LH \& Maxwell WM 2009 Factors influencing the "sortability" of stallion spermatozoa into X- and Y-chromosome bearing populations. Animal Reproduction Science 113 220-228. (doi:10.1016/j.anireprosci.2008.08.019)

Cran DG \& Johnson LA 1996 The predetermination of embryonic sex using flow cytometrically separated $\mathrm{X}$ and $\mathrm{Y}$ spermatozoa. Human Reproduction Update 2 355-363. (doi:10.1093/humupd/2.4.355)

Cran DG, Johnson LA, Miller NG, Cochrane D \& Polge C 1993 Production of bovine calves following separation of $\mathrm{X}$ - and Y-chromosome bearing sperm and in vitro fertilisation. Veterinary Record 132 40-41. (doi:10.1136/vr.132.2.40)

De Ambrogi M, Spinaci M, Galeati G \& Tamanini C 2006 Viability and DNA fragmentation in differently sorted boar spermatozoa. Theriogenology 66 1994-2000. (doi:10.1016/j.theriogenology.2006.05.017)

Dean PN, Pinkel D \& Mendelsohn ML 1978 Hydrodynamic orientation of sperm heads for flow cytometry. Biophysical Journal 23 7-13. (doi:10.1016/S0006-3495(78)85428-9)

De Cecco M, Spinaci M, Zannoni A, Bernardini C, Seren E, Forni M \& Bacci ML 2010 Coupling sperm mediated gene transfer and sperm sorting techniques: a new perspective for swine transgenesis. Theriogenology $\mathbf{7 4}$ 856-862. (doi:10.1016/j.theriogenology.2010.04.010)

Dejarnette JM, Nebel RL \& Marshall CE 2009 Evaluating the success of sexsorted semen in U.S. dairy herds from on farm records. Theriogenology 71 49-58. (doi:10.1016/j.theriogenology.2008.09.042)

Dejarnette JM, Leach MA, Nebel RL, Marshall CE, McCleary CR \& Moreno JF 2011 Effects of sex-sorting and sperm dosage on conception rates of Holstein heifers: is comparable fertility of sex-sorted and conventional semen plausible? Journal of Dairy Science 94 3477-3483. (doi:10.3168/jds.2011-4214) 
De Jong WH, Hagens WI, Krystek P, Burger MC, Sips AJ \& Gertsma RE 2008 Particle size dependent organ distribution of gold nanoparticles after intravenous administration. Biomaterials 29 1912-1919. (doi:10.1016/ j.biomaterials.2007.12.037)

De Martino C, Floridi A, Marcante M, Malorni W, Barcellona P, Bellocci M \& Silvestrini B 1979 Morphological, histochemical and biochemical studies on germ cell mitochondria of normal rats. Cell and Tissue Research 196 1-22.

Den Daas JH, De Jong G, Lansbergen LM \& Van Wagtendonk-De Leeuw AM 1998 The relationship between the number of spermatozoa inseminated and the reproductive efficiency of individual dairy bulls. Journal of Dairy Science 81 1714-1723. (doi:10.3168/jds.S0022-0302 (98)75739-X)

Derossi D, Joliot AH, Chassaing G \& Prochiantz A 1994 The third helix of the antennapedia homeodomain translocates through biological membranes. Journal of Biological Chemistry 269 10444-10450.

De Vries A, Overton M, Fetrow J, Leslie K, Eicker S \& Rogers G 2008 Exploring the impact of sexed semen on the structure of the dairy industry. Journal of Dairy Science 91 847-856. (doi:10.3168/ jds.2007-0536)

Ema M, Kobayashi N, Naya M, Hanai S \& Nakanishi J 2010 Reproductive and developmental toxicity studies of manufactured nanomaterials. Reproductive Toxicology 30 343-352. (doi:10.1016/j.reprotox.2010.06. 002)

Everts M, Saini V, Leddon JL, Kok RJ, Stoff-Khalili M, Preuss MA, Millican CL, Perkins G, Brown JM, Bagaria H et al. 2006 Covalently linked $\mathrm{Au}$ nanoparticles to a viral vector: potential for combined photothermal and gene cancer therapy. Nano Letters 6 587-591. (doi:10.1021/nl0500555)

de la Fuente JM \& Berry CC 2005 Tat peptide as an efficient molecule to translocate gold nanoparticles into the cell nucleus. Bioconjugate Chemistry 16 1176-1180. (doi:10.1021/bc050033+)

Fulwyler MJ 1977 Hydrodynamic orientation of cells. Journal of Histochemistry and Cytochemistry 25 781-783. (doi:10.1177/25.7.330728)

Gagne MB, Pothier F \& Sirard MA 1991 Electroporation of bovine spermatozoa to carry foreign DNA in oocytes. Molecular Reproduction and Development 29 6-15. (doi:10.1002/mrd.1080290103)

Gao HJ, Shi WD \& Freund LB 2005 Mechanics of receptor-mediated endocytosis. PNAS 102 9469-9474. (doi:10.1073/pnas.0503879102)

Garner DL 2009 Hoechst 33342: the dye that enabled differentiation of living X-and Y-chromosome bearing mammalian sperm. Theriogenology 71 11-21. (doi:10.1016/j.theriogenology.2008.09.023)

Garner DL, Gledhill BL, Pinkel D, Lake S, Stephenson D, Van Dilla MA \& Johnson LA 1983 Quantification of the X- and Y-chromosome-bearing spermatozoa of domestic animals by flow cytometry. Biology of Reproduction 28 312-321. (doi:10.1095/biolreprod28.2.312)

Garrels W, Holler S, Taylor U, Herrmann D, Struckmann C, Klein S, Barg-Kues B, Nowak-Imialek M, Ehling C, Rath D et al. 2011 Genotype-independent transmission of transgenic fluorophore protein by boar spermatozoa. PLoS ONE 6 e27563. (doi:10.1371/journal.pone. 0027563)

Gibb Z, Morris LH, Maxwell WM \& Grupen CG 2011 Use of a defined diluent increases the sex-sorting efficiency of stallion sperm. Theriogenology 75 610-619. (doi:10.1016/j.theriogenology.2010.10.001)

Gledhill BL, Pinkel D, Garner DL \& Van Della MA 1982 Identifying $\mathrm{X}$ - and Y-chromosome-bearing sperm by DNA content: retrospective perspectives and prospective opinions. In Prospects for Sexing Mammalian Sperm, pp 177-191. Eds RP Amann\& GE Seidel. Boulder, CO, USA: Colorado Associated University Press.

de Graaf SP, Evans G, Maxwell WMC \& O'Brien JK 2006 In vitro function of fresh and frozen-thawed ram spermatozoa after sex-sorting and re-freezing. Reproduction, Fertility, and Development 18 867-874. (doi:10.1071/RD06061)

de Graaf SP, Beilby KH, O'Brien JK, Osborn D, Downing JA, Maxwell WMC \& Evans G 2007a Embryo production from superovulated sheep inseminated with sex-sorted ram spermatozoa. Theriogenology 67 550-555. (doi:10.1016/j.theriogenology.2006.09.002)

de Graaf SP, Evans G, Maxwell WMC, Cran DG \& O'Brien JK $2007 b$ Birth of offspring of pre-determined sex after artificial insemination of frozen-thawed, sex-sorted and re-frozen-thawed ram spermatozoa. Theriogenology 67 391-398. (doi:10.1016/j.theriogenology.2006.08. 005) de Graaf SP, Evans G, Maxwell WMC, Downing JA \& O'Brien JK 2007 C Successful low dose insemination of flow cytometrically sorted ram spermatozoa in sheep. Reproduction in Domestic Animals 42 648-653. (doi:10.1111/j.1439-0531.2006.00837.x)

de Graaf SP, Beilby KH, Underwood SL, Evans G \& Maxwell WMC 2009 Sperm sexing in sheep and cattle: the exception and the rule. Theriogenology 71 89-97. (doi:10.1016/j.theriogenology.2008.09.014)

Green M \& Loewenstein PM 1988 Autonomous functional domains of chemically synthesized human immunodeficiency virus tat transactivator protein. Cell 55 1179-1188. (doi:10.1016/0092-8674(88)90262-0)

Grossfeld R, Klinc P, Sieg B \& Rath D 2005 Production of piglets with sexed semen employing a non-surgical insemination technique. Theriogenology 63 2269-2277. (doi:10.1016/j.theriogenology.2004.10.004)

Grossfeld R, Strothmeyer M \& Rath D 2011 Low dose sperm intra fallopian transfer (SIFT) in dairy cows. Reproduction in Domestic Animals $\mathbf{4 6}$ (Suppl 3) 109 (Abstr). (doi:10.1111/j.1439-0531.2011.01839.x)

Guthrie HD, Johnson LA, Garrett WM, Welch GR \& Dobrinsky JR 2002 Flow cytometric sperm sorting: effects of varying laser power on embryo development in swine. Molecular Reproduction and Development 61 87-92. (doi:10.1002/mrd.1134)

Hayakawa H, Hirai T, Takimoto A, Ideta A \& Aoyagi Y 2009 Superovulation and embryo transfer in Holstein cattle using sexed sperm. Theriogenology 71 68-73. (doi:10.1016/j.theriogenology.2008.09.016)

Heer P 2007 Anpassung der Konservierungsprozesse fuer Hengstsperma an die Beltsville Sperm Sexing Technology [Adjustment of the cryopreservation of stallion spermatozoa to the Beltsville Sperm Sexing Technology]. $P h D$ Thesis. University of Veterinary Medicine Hannover, Germany.

Hollinshead FK, O'Brien JK, Maxwell WMC \& Evans G 2002 Production of lambs of predetermined sex after the insemination of ewes with low numbers of frozen-thawed sorted X- or Y-chromosome-bearing spermatozoa. Reproduction, Fertility, and Development 14 503-508. (doi:10.1071/RD02034)

Hollinshead FK, Gillan L, O'Brien JK, Evans G \& Maxwell WMC 2003 In vitro and in vivo assessment of functional capacity of flow cytometrically sorted ram spermatozoa after freezing and thawing. Reproduction, Fertility, and Development 15 351-359. (doi:10.1071/RD03060)

Hollinshead FK, Evans G, Evans KM, Catt SL, Maxwell WMC \& O'Brien JK 2004 Birth of lambs of a pre-determined sex after in vitro production of embryos using frozen-thawed sex-sorted and re-frozen-thawed ram spermatozoa. Reproduction 127 557-568. (doi:10.1530/rep.1.00049)

Hoogsteen K 1963 Crystal and molecular structure of a hydrogen-bonded complex between 1-methylthymine and 9-methyladenine. Acta Crystallographica 16 907-916. (doi:10.1107/S0365110X63002437)

Jain PK, El-Sayed IH \& El-Sayed MA 2007 Au nanoparticles target cancer. Nano Today 2 18-29. (doi:10.1016/S1748-0132(07)70016-6)

Jiang W, Kim BYS, Rutka JT \& Chan WCW 2008 Nanoparticle-mediated cellular response is size-dependent. Nature Nanotechnology 3 145-150. (doi:10.1038/nnano.2008.30)

Johnson LA \& Pinkel D 1986 Modification of a laser-based flow cytometer for high-resolution DNA analysis of mammalian spermatozoa. Cytometry 7 268-273. (doi:10.1002/cyto.990070307)

Johnson LA \& Clarke RN 1988 Flow sorting of $X$ and $Y$ chromosomebearing mammalian sperm: activation and pronuclear development of sorted bull, boar, and ram sperm microinjected into hamster oocytes. Gamete Research 21 335-343. (doi:10.1002/mrd.1120210402)

Johnson MD \& Fresco JR 1999a Third-strand in situ hybridization (TISH) to non-denatured metaphase spreads and interphase nuclei. Chromosoma 108 181-189. (doi:10.1007/s004120050367)

Johnson LA \& Welch GR 1999b Sex preselection: high-speed flow cytometric sorting of $\mathrm{X}$ and $\mathrm{Y}$ sperm for maximum efficiency. Theriogenology 52 1323-1341. (doi:10.1016/S0093-691X(99)00220-4)

Johnson LA, Flook JP \& Look MV 1987a Flow cytometry of $X$ and $Y$ chromosome-bearing sperm for DNA using an improved preparation method and staining with Hoechst 33342. Gamete Research 17 203-212. (doi:10.1002/mrd.1120170303)

Johnson LA, Flook JP, Look MV \& Pinkel D $1987 b$ Flow sorting of $X$ and $Y$ chromosome-bearing spermatozoa into two populations. Gamete Research 16 1-9. (doi:10.1002/mrd.1120160102)

Johnson LA, Welch GR \& Rens W 1999 The Beltsville Sperm Sexing Technology: high-speed sperm sorting gives improved sperm output for in vitro fertilization and Al. Journal of Animal Science 77 (Suppl 2) 213-220. 
Kawarasaki T, Welch GR, Long CR, Yoshida M \& Johnson LA 1998 Verification of flow cytometrically-sorted $X$ - and Y-bearing porcine spermatozoa and reanalysis of spermatozoa for DNA content using the fluorescence in situ hybridization (FISH) technique. Theriogenology $\mathbf{5 0}$ 625-635. (doi:10.1016/S0093-691X(98)00167-8)

Klein S, Petersen S, Taylor U, Barcikowski S \& Rath D 2010 Quantitative visualization of colloidal and intracellular gold nanoparticles by confocal microscopy. Journal of Biomedical Optics 15036015. (doi:10.1117/1.3461170)

Klinc P 2005 Improved fertility of flowcytometrically sex selected bull spermatozoa. PhD Thesis. University of Veterinary Medicine Hannover, Germany.

Klinc P \& Rath D 2007 Reduction of oxidative stress in bovine spermatozoa during flow cytometric sorting. Reproduction in Domestic Animals 42 63-67. (doi:10.1111/j.1439-0531.2006.00730.x)

Klinc P, Frese D, Osmers H \& Rath D 2007 Insemination with sex sorted fresh bovine spermatozoa processed in the presence of antioxidative substances. Reproduction in Domestic Animals 42 58-62. (doi:10.1111/ j.1439-0531.2006.00729.x)

Krueger C \& Rath D 2000 Intrauterine insemination in sows with reduced sperm number. Reproduction, Fertility, and Development 12 113-117. (doi:10.1071/RD00035)

Kues W, Sudheer S, Herrmann D, Carnwath JW, Havlicek V, Besenfelder U, Lehrach H, Adjaye J \& Niemann H 2008a Genome-wide expression profiling reveals distinct clusters of transcriptional regulation during bovine preimplantation development in vivo. PNAS 105 19768-19773. (doi:10.1073/pnas.0805616105)

Kues W, Rath D \& Niemann H 2008b Reproductive biotechnology in farm animals goes genomics. CAB Reviews 3 036. (doi:10.1079/PAVS NNR20083036)

de Lamirande E, Jiang H, Zini A, Kodama H \& Gagnon C 1997 Reactive oxygen species and sperm physiology. Reviews of Reproduction 2 48-54.

Leahy T, Celi P, Bathgate R, Evans G, Maxwell WM \& Marti JI 2010 Flow-sorted ram spermatozoa are highly susceptible to hydrogen peroxide damage but are protected by seminal plasma and catalase. Reproduction, Fertility, and Development 22 1131-1140. (doi:10.1071/ RD09286)

Lindsey AC, Morris LH, Allen WR, Schenk JL, Squires EL \& Bruemmer JE 2002 Hysteroscopic insemination of mares with low numbers of nonsorted or flow sorted spermatozoa. Equine Veterinary Journal 34 128-132. (doi:10.2746/042516402776767178)

Liu HT, Niu RY, Wang JM, He Y \& Wang JD 2008 Changes caused by fluoride and lead in energy metabolic enzyme activities in the reproductive system of male offspring rats. Flouride 41 184-191.

Lu KH, Cran DG \& Seidel GE Jr 1999 In vitro fertilization with flowcytometrically-sorted bovine sperm. Theriogenology 52 1393-1405. (doi:10.1016/S0093-691X(99)00225-3)

Lundberg M \& Johansson M 2002 Positively charged DNA-binding proteins cause apparent cell membrane translocation. Biochemical and Biophysical Research Communications 291 367-371. (doi:10.1006/ bbrc.2002.6450)

Mandal D, Maran A, Yaszemski MJ, Bolander ME \& Sarkar G 2009 Cellular uptake of gold nanoparticles directly cross-linked with carrier peptides by osteosarcoma cells. Journal of Materials Science: Materials in Medicine 20 347-350. (doi:10.1007/s10856-008-3588-x)

Martinez EA, Vazquez JM, Roca J, Lucas X, Gil MA \& Vazquez JL 2001 Deep intrauterine insemination and embryo transfer in pigs. Reproduction Supplement 58 301-311.

Maxwell WM \& Johnson LA 1997 Chlortetracycline analysis of boar spermatozoa after incubation, flow cytometric sorting, cooling, or cryopreservation. Molecular Reproduction and Development 46 408-418. (doi:10.1002/(SICl)1098-2795(199703)46:3 < 408::AID-MRD21 $>3.0 . \mathrm{CO} ; 2-\mathrm{T})$

McKenzie F, Faulds K \& Graham D 2008 LNA functionalized gold nanoparticles as probes for double stranded DNA through triplex formation. Chemical Communications 20 2367-2369. (doi:10.1039/b802163e)

Meinhardt A, McFarlane JR, Seitz J \& de Kretser DM 2000 Activin maintains the condensed type of mitochondria in germ cells. Molecular and Cellular Endocrinology 168 111-117. (doi:10.1016/S0303-7207 (00)00308-7)
Merton JS, Haring RM, Stap J, Hoebe RA \& Aten JA 1997 Effect of flow cytometrically sorted sperm on success rate of in vitro bovine embryo production. Theriogenology 47 295. (doi:10.1016/S0093-691X (97)82422-3)

Moench-Tegeder G 2008 Auswirkungen verschiedener spermaaufbereitungen auf die lebensfähigkeit geschlechtsspezifisch differenzierter spermatozoen. Masters Thesis. Faculty of Agricultural Sciences, University of Göttingen, Germany

Moench-Tegeder G 2011 Einfluss Verschiedener Ejakulatbehandlungen auf die Lebensfähigkeit und das Befruchtungspotential Geschlechtsspezifisch Differenzierter Bullenspermien [Effect of different ejaculate treatments on viability and fertilizing capacity of sex sorted bull spermatozoa]. PhD Thesis. Faculty of Agricultural Sciences, University of Göttingen, Germany.

Morrell JM, Keeler KD, Noakes DE, Mackenzie NM \& Dresser DW 1988 Sexing of sperm by flow cytometry. Veterinary Record 122 322-324. (doi:10.1136/vr.122.14.322)

Morris LH, Hunter RH \& Allen WR 2000 Hysteroscopic insemination of small numbers of spermatozoa at the uterotubal junction of preovulatory mares. Journal of Reproduction and Fertility 118 95-100. (doi:10.1530/ reprod/118.1.95)

Morton KM, Bathgate R, Evans G \& Maxwell WM 2007a Cryopreservation of epididymal alpaca (Vicugna pacos) sperm: a comparison of citrate-, tris- and lactose-based diluents and pellets and straws. Reproduction, Fertility, and Development 19 792-796. (doi:10.1071/RD07049)

Morton KM, Herrmann D, Sieg B, Struckmann C, Maxwell WM, Rath D, Evans G, Lucas-Hahn A, Niemann H \& Wrenzycki C 2007b Altered mRNA expression patterns in bovine blastocysts after fertilisation in vitro using flow-cytometrically sex-sorted sperm. Molecular Reproduction and Development 74 931-940. (doi:10.1002/mrd.20573)

van Munster EB 2002 Interferometry in flow to sort unstained X- and Y-chromosome-bearing bull spermatozoa. Cytometry 47 192-199. (doi:10.1002/cyto.10064)

Nativo P, Prior IA \& Brust M 2008 Uptake and intracellular fate of surfacemodified gold nanoparticles. ACS Nano 2 1639-1644. (doi:10.1021/ nn800330a)

Nel AE, Madler L, Velegol D, Xia T, Hoek EMV, Somasundaran P, Klaessig F, Castranova V \& Thompson M 2009 Understanding biophysicochemical interactions at the nano-bio interface. Nature Materials 8 543-557. (doi:10.1038/nmat2442)

Niemann H, Kuhla B \& Flachowsky G 2011 Perspectives for feedefficient animal production. Journal of Animal Science 89 4344-4363. (doi:10.2527/jas.2011-4235)

Norman HD, Hutchison JL \& Miller RH 2010 Use of sexed semen and its effect on conception rate, calf sex, dystocia, and stillbirth of Holstein in the United States. Journal of Dairy Science 93 3880-3890. (doi:10.3168/ jds.2009-2781)

O'Brien JK, Hollinshead FK, Evans KM, Evans G \& Maxwell WMC 2003 Flow cytometric sorting of frozen-thawed spermatozoa in sheep and non-human primates. Reproduction, Fertility, and Development 15 367-375. (doi:10.1071/RD03065)

O'Brien JK, Steinman KJ \& Robeck TR 2009 Application of sperm sorting and associated reproductive technology for wildlife management and conservation. Theriogenology 71 98-107. (doi:10.1016/j.theriogenology.2008.09.052)

Okunade GW, Miller ML, Pyne GJ, Sutliff RL, O'Connor KT, Neumann JC, Andringa A, Miller DA, Prasad V, Doetschman T et al. 2004 Targeted ablation of plasma membrane $\mathrm{Ca}^{2+}$-ATPase (PMCA) 1 and 4 indicates a major housekeeping function for PMCA1 and a critical role in hyperactivated sperm motility and male fertility for PMCA4. Journal of Biological Chemistry 279 33742-33750. (doi:10.1074/jbc.M40462 8200)

Palma GA, Olivier NS, Neumuller C \& Sinowatz F 2008 Effects of sex-sorted spermatozoa on the efficiency of in vitro fertilization and ultrastructure of in vitro produced bovine blastocysts. Anatomia, Histologia, Embryologia 37 67-73.

Pelliccione F, Micillo A, Cordeschi G, D'Angeli A, Necozione S, Gandini L, Lenzi A, Francavilla F \& Francavilla S 2011 Altered ultrastructure of mitochondrial membranes is strongly associated with unexplained asthenozoospermia. Fertility and Sterility 95 641-646. (doi:10.1016/ j.fertnstert.2010.07.1086) 
Petersen S, Barchanski A, Taylor U, Klein S, Rath D \& Barcikowski S 2011 Penetratin-conjugated gold nanoparticles: design of cell penetrating nanomarker by laser ablation. Bioconjugate Chemistry 115 5152-5159. (doi:10.1021/jp1093614).

Pinkel D, Gledhill BL, Lake S, Stephenson D \& Van Dilla MA 1982 Sex preselection in mammals? Separation of sperm bearing $\mathrm{Y}$ and " $\mathrm{O}$ " chromosomes in the vole Microtus oregoni Science 218 904-906. (doi:10.1126/science.6753153)

Piomboni P, Focarelli R, Stendardi A, Ferramosca A \& Zara V 2012 The role of mitochondria in energy production for human sperm motility. International Journal of Andrology 35 109-124. (doi:10.1111/j.13652605.2011.01218.x)

Probst S \& Rath D 2003 Production of piglets using intracytoplasmic sperm injection (ICSI) with flowcytometrically sorted boar semen and artificially activated oocytes. Theriogenology 59 961-973. (doi:10.1016/S0093691X(02)01135-4)

Rahmy TR \& Ayoub MA 2002 In vitro action of cobra venom on goat spermatozoa ultrastructure by transmission and scanning electron microscopy. Journal of Venomous Animals and Toxins 8 127-159. (doi:10.1590/S0104-79302002000100011)

Rath D \& Johnson LA 2008 Application and commercialization of flow cytometrically sex-sorted semen. Reproduction in Domestic Animals 43 (Suppl 2) 338-346. (doi:10.1111/j.1439-0531.2008.01182.x)

Rath D, Johnson LA \& Welch GR 1993 In vitro culture of porcine embryos: development to blastocysts after in vitro fertilization (IVF) with flow cytometrically sorted and unsorted semen. Theriogenology 39293 (Abstr). (doi:10.1016/0093-691X(93)90148-X)

Rath D, Johnson LA, Welch GR \& Niemann H 1994 Successful gamete intrafallopian transfer (GIFT) in the porcine. Theriogenology 41 1173-1179. (doi:10.1016/S0093-691X(05)80039-1)

Rath D, Johnson LA, Dobrinsky JR, Welch GR \& Niemann H 1997 Production of piglets preselected for sex following in vitro fertilization with $X$ and $Y$ chromosome-bearing spermatozoa sorted by flow cytometry. Theriogenology 47 795-800. (doi:10.1016/S0093-691X(97) 00035-6)

Rath D, Long CR, Dobrinsky JR, Welch GR, Schreier LL \& Johnson LA 1999 In vitro production of sexed embryos for gender preselection: high-speed sorting of X-chromosome-bearing sperm to produce pigs after embryo transfer. Journal of Animal Science 77 3346-3352.

Rath D, Ruiz S \& Sieg B 2003 Birth of female piglets following intrauterine insemination of a sow using flow cytometrically sexed boar semen. Veterinary Record 152 400-401. (doi:10.1136/vr.152.13.400)

Rath D, Bathgate R, Rodriguez-Martinez H, Roca J, Strzezek J \& Waberski D 2009a Recent advances in boar semen cryopreservation. Society of Reproduction and Fertility Supplement 66 51-66.

Rath D, Moench-Tegeder G, Taylor U \& Johnson LA 2009b Improved quality of sex-sorted sperm: a prerequisite for wider commercial application. Theriogenology 71 22-29. (doi:10.1016/j.theriogenology. 2008.09.027)

Rens W, Welch GR \& Johnson LA 1998 A novel nozzle for more efficient sperm orientation to improve sorting efficiency of $X$ and $Y$ chromosomebearing sperm. Cytometry 33 476-481. (doi:10.1002/(SICl)10970320(19981201)33:4<476::AID-CYTO12>3.0.CO;2-B)

Rigby SL, Brinsko SP, Cochran M, Blanchard TL, Love CC \& Varner DD 2001 Advances in cooled semen technologies: seminal plasma and semen extender. Animal Reproduction Science 68 171-180. (doi:10.1016/S03784320(01)00154-3)

Salmaso S, Caliceti P, Amendola V, Meneghetti M, Magnusson JP Pasparakis G \& Alexander C 2009 Cell up-take control of gold nanoparticles functionalized with a thermoresponsive polymer Journal of Materials Chemistry 19 1608-1615. (doi:10.1039/b816603j)

Sauer H, Bekhite MM, Hescheler J \& Wartenberg M 2005 Redox control of angiogenic factors and CD31-positive vessel-like structures in mouse embryonic stem cells after direct current electrical field stimulation. Experimental Cell Research 304 380-390. (doi:10.1016/j.yexcr.2004. 11.026)

Schenk JL \& Seidel GE Jr 2007 Pregnancy rates in cattle with cryopreserved sexed spermatozoa: effects of laser intensity, staining conditions and catalase. Society of Reproduction and Fertility Supplement $\mathbf{6 4}$ 165-177.
Schenk JL, Suh TK \& Seidel GE Jr 2006 Embryo production from superovulated cattle following insemination of sexed sperm. Theriogenology 65 299-307. (doi:10.1016/j.theriogenology.2005.04.026)

Schenk JL, Cran DG, Everett RW \& Seidel GE Jr 2009 Pregnancy rates in heifers and cows with cryopreserved sexed sperm: effects of sperm numbers per inseminate, sorting pressure and sperm storage before sorting. Theriogenology 71 717-728. (doi:10.1016/j.theriogenology. 2008.08.016)

Schuberth HJ, Taylor U, Zerbe H, Waberski D, Hunter R \& Rath D 2008 Immunological responses to semen in the female genital tract. Theriogenology 70 1174-1181. (doi:10.1016/j.theriogenology.2008. 07.020)

Schrand AM, Rahman MF, Hussain SM, Schlager JJ, Smith DA \& Syed AF 2010 Metal-based nanoparticles and their toxicity assessment. Wiley Interdisciplinary Reviews. Nanomedicine and Nanobiotechnology 2 544-568. (doi:10.1002/wnan.103)

Schwarz-Finsterle J, Stein S, Grossmann C, Schmitt E, Trakhtenbrot L, Rechavi G, Amariglio N, Cremer C \& Hausmann M 2007 Comparison of triple helical COMBO-FISH and standard FISH by means of quantitative microscopic image analysis of abl/bcr positions in cell nuclei. Journal of Biochemical and Biophysical Methods 70 397-406. (doi:10.1016/j. jbbm.2006.09.004)

Seidel GE Jr, Schenk JL, Herickhoff LA, Doyle SP, Brink Z, Green RD \& Cran DG 1999 Insemination of heifers with sexed sperm. Theriogenology 52 1407-1420. (doi:10.1016/S0093-691X(99)00226-5)

Seidman MM \& Glazer PM 2003 The potential for gene repair via triple helix formation. Journal of Clinical Investigation 112 487-494.

Sharpe JC \& Evans KM 2009 Advances in flow cytometry for sperm sexing. Theriogenology 71 4-10. (doi:10.1016/j.theriogenology.2008.09.021)

Shi XG, Wang SH, Meshinchi S, Van Antwerp ME, Bi XD, Lee IH \& Baker JR 2007 Dendrimer-entrapped gold nanoparticles as a platform for cancercell targeting and Imaging. Small 3 1245-1252. (doi:10.1002/smll. 200700054)

Shi TY, Chen G, Huang X, Yuan Y, Wu X, Wu B, Li Z, Shun F, Chen H \& Shi H 2012 Effects of reactive oxygen species from activated leucocytes on human sperm motility, viability and morphology. Andrologia $\mathbf{4 4}$ (Suppl 1) 696-703.

Shukla R, Bansal V, Chaudhary M, Basu A, Bhonde RR \& Sastry M 2000 Biocompatibility of gold nanoparticles and their endocytotic fate inside the cellular compartment: a microscopic overview. Langmuir: The ACS Journal of Surfaces and Colloids 21 10644-10654. (doi:10.1021/ la0513712)

Simpson AM, Swan MA \& White IG 1986 Action of phosphatidylcholine in protecting ram sperm from cold shock. Gamete Research 15 43-56. (doi:10.1002/mrd.1120150106)

Simpson AM, Swan MA \& White IG 1987 Calcium uptake, respiration, and ultrastructure of sperm exposed to ionophore A23187. Archives of Andrology 19 5-18. (doi:10.3109/01485018708986795)

Spinaci M, Volpe S, Bernardini C, de Ambrogi M, Tamanini C, Seren E \& Galeati G 2006 Sperm sorting procedure induces a redistribution of Hsp70 but not Hsp60 and Hsp90 in boar spermatozoa. Journal of Andrology 27 899-907. (doi:10.2164/jandrol.106.001008)

Spinaci M, Vallorani C, Bucci D, Bernardini C, Tamanini C, Seren E \& Galeati G 2010 Effect of liquid storage on sorted boar spermatozoa. Theriogenology 74 741-748. (doi:10.1016/j.theriogenology. 2010.03.027)

Stap J, Hoebe RA, Merton JS, Haring RM, Bakker PJM \& Aten JA 1998 Improving the resolution of cryopreserved $\mathrm{X}$ - and Y-sperm during DNA flow cytometric analysis with the addition of Percoll to quench the fluorescence of dead sperm. Journal of Animal Science $\mathbf{7 6}$ 1896-1902.

Stewart KM, Horton KL \& Kelley SO 2008 Cell-penetrating peptides as delivery vehicles for biology and medicine. Organic \& Biomolecular Chemistry 6 2242-2255. (doi:10.1039/b719950c)

Storey BT 2008 Mammalian sperm metabolism: oxygen and sugar, friend and foe. International Journal of Developmental Biology 52 427-437. (doi:10.1387/ijdb.072522bs)

Stovel RT, Sweet RG \& Herzenberg LA 1978 A means for orienting flat cells in flow systems. Biophysical Journal 23 1-5. (doi:10.1016/S0006-3495 (78)85427-7) 
Sun Z, Niu R, Su K, Wang B, Wang J, Zhang J \& Wang J 2010 Effects of sodium fluoride on hyperactivation and $\mathrm{Ca}^{2+}$ signalling pathways in sperm from mice: an in vivo study. Archives of Toxicology 84 351-361. (doi:10.1007/s00204-009-0508-x)

Tomkins PT \& Houghton JA 1988 The rapid induction of the acrosome reaction of human spermatozoa by electropermeabilization. Fertility and Sterility 50 329-336.

Taylor U, Rath D, Zerbe H \& Schuberth HJ 2008 Interaction of intact porcine spermatozoa with epithelial cells and neutrophilic granulocytes during uterine passage. Reproduction in Domestic Animals 43 166-175. (doi:10.1111/j.1439-0531.2007.00872.x)

Taylor U, Schuberth HJ, Rath D, Michelmann HW, Sauter-Louis C \& Zerbe H 2009a Influence of inseminate components on porcine leucocyte migration in vitro and in vivo after pre- and post-ovulatory insemination. Reproduction in Domestic Animals 44 180-188. (doi:10.1111/j.1439-0531.2007.01015.x)

Taylor U, Zerbe H, Seyfert HM, Rath D, Baulain U, Langner KF \& Schuberth HJ 2009 $b$ Porcine spermatozoa inhibit post-breeding cytokine induction in uterine epithelial cells in vivo. Animal Reproduction Science 115 279-289. (doi:10.1016/j.anireprosci.2008.11.019)

Taylor U, Zerbe H, Seyfert HM, Rath D \& Schuberth HJ 2009c Binding of porcine spermatozoa to uterine epithelial cells modulates the female immune response and might indicate the formation of a pre-oviductal sperm reservoir. Society of Reproduction and Fertility Supplement 66 83-84.

Taylor U, Klein S, Petersen S, Kues W, Barcikowski S \& Rath D 2010 Nonendosomal cellular uptake of ligand-free, positively charged gold nanoparticles. Cytometry. Part A 77 439-446. (doi:10.1002/cyto. a.20846)

Taylor U, Barchanski A, Garrels W, Klein S, Kues W, Barcikowski S \& Rath D 2012 Toxicity of gold nanoparticles on somatic and reproductive cells. Advances in Experimental Medicine and Biology 733 125-133. (doi:10.1007/978-94-007-2555-3_12)

Tkachenko AG, Xie H, Liu YL, Coleman D, Ryan J, Glomm WR, Shipton MK, Franzen S \& Feldheim DL 2004 Cellular trajectories of peptide-modified gold particle complexes: comparison of nuclear localization signals and peptide transduction domains. Bioconjugate Chemistry 15 482-490. (doi:10.1021/bc034189q)

Underwood SL, Bathgate R, Maxwell WMC \& Evans G 2009a Development of procedures for sex-sorting frozen-thawed bovine spermatozoa. Reproduction in Domestic Animals 44 460-466. (doi:10.1111/j.14390531.2008.01127.x)

Underwood SL, Bathgate R, Maxwell WMC \& Evans G 2009b In vitro characteristics of frozen-thawed, sex-sorted bull sperm after refreezing or incubation at 15 or $37^{\circ} \mathrm{C}$. Theriogenology 72 1001-1008. (doi:10.1016/j.theriogenology.2009.06.023)

Underwood SL, Bathgate R, Ebsworth M, Maxwell WMC \& Evans G 2010a Pregnancy loss in heifers after artificial insemination with frozen-thawed, sex-sorted, re-frozen-thawed dairy bull sperm. Animal Reproduction Science 118 7-12. (doi:10.1016/j.anireprosci.2009.06.004)

Underwood SL, Bathgate R, Maxwell WMC \& Evans G 2010b Birth of offspring after artificial insemination of heifers with frozen-thawed, sex-sorted, re-frozen-thawed bull sperm. Animal Reproduction Science 118 171-175. (doi:10.1016/j.anireprosci.2009.08.007)
Underwood SL, Bathgate R, Pereira DC, Castro A, Thomson PC, Maxwell WMC \& Evans G 2010c Embryo production after in vitro fertilization with frozen-thawed, sex-sorted, re-frozen-thawed bull sperm. Theriogenology 73 97-102. (doi:10.1016/j.theriogenology. 2009.08.005)

Van Dilla MA, Gledhill BL, Lake S, Dean PN, Gray JW, Kachel V, Barlogie B \& Gohde W 1977 Measurement of mammalian sperm deoxyribonucleic acid by flow cytometry. Problems and approaches. Journal of Histochemistry and Cytochemistry 25 763-773. (doi:10.1177/ 25.7.70455)

Vazquez JM, Martinez EA, Parrilla I, Roca J, Gil MA \& Vazquez JL 2003 Birth of piglets after deep intrauterine insemination with flow cytometrically sorted boar spermatozoa. Theriogenology 59 1605-1614. (doi:10.1016/ S0093-691X(02)01198-6)

Vazquez JM, Martinez EA, Roca J, Gil MA, Parrilla I, Cuello C, Carvajal G, Lucas X \& Vazquez JL 2005 Improving the efficiency of sperm technologies in pigs: the value of deep intrauterine insemination. Theriogenology 63 536-547. (doi:10.1016/j.theriogenology. 2004.09.043)

Vazquez JM, Roca J, Gil MA, Cuello C, Parrilla I, Caballero I, Vazquez JL \& Martinez EA 2008 Low-dose insemination in pigs: problems and possibilities. Reproduction in Domestic Animals 43 (Suppl 2) 347-354. (doi:10.1111/j.1439-0531.2008.01183.x)

Verma A, Uzun O, Hu YH, Hu Y, Han HS, Watson N, Chen SL, Irvine DJ \& Stellacci F 2008 Surface structure-regulated cell-membrane penetration by monolayer protected nanoparticles. Nature Materials 7 588-595. (doi:10.1038/nmat2202)

Weiss L \& Zeigel R 1971 Cell surface negativity and binding of positively charged particles. Journal of Cellular Physiology 77 179-186. (doi:10.1002/jcp.1040770208)

Xu J, Guo Z, Su L, Nedambale TL, Zhang J, Schenk J, Moreno JF, Dinnyés A, Ji W, Tian XC et al. 2006 Developmental potential of vitrified Holstein cattle embryos fertilized in vitro with sex-sorted sperm. Journal of Dairy Science 89 2510-2518. (doi:10.3168/jds. S0022-0302(06)72326-8)

Zakrzewska H \& Udala J 2006 In vitro influence of sodium fluoride on adenosine triphosphate (ATP) content in ram semen. Annales Academiae Medicae Stetinensis 52 (Suppl 1) 109-111.

Zakrzewska H, Udala J \& Blaszczykb B 2002 In vitro influence of sodium fluoride on ram semen quality and enzyme activities. Fluoride $\mathbf{3 5}$ 153-160. (doi:10.2147/IJN.S8428)

Zhang XD, Wu HY, Wu D, Wang YY, Chang JH, Zhai ZB, Meng AM, Liu PX, Zhang LA \& Fan FY 2010 Toxicologic effects of gold nanoparticles in vivo by different administration routes. International Journal of Nanomedicine 5 771-781. (doi:10.2147/IJN.S8428)

Received 23 April 2012

First decision 19 June 2012

Revised manuscript received 1 November 2012

Accepted 12 November 2012 